
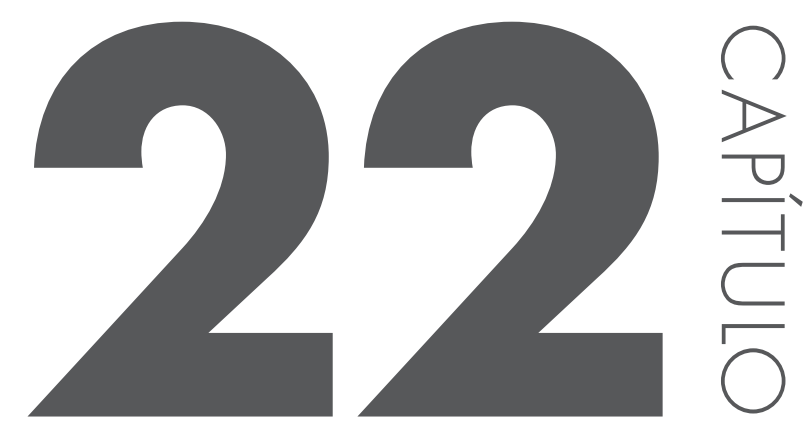

\title{
DIGESTÃO E ABSORC̣̃̃O DE NUTRIENTES ORGÂNICOS
}

Sônia Malheiros Lopes Sanioto

\subsection{INTRODUÇÃO}

Os processos digestivos dos nutrientes orgânicos são efetuados por enzimas luminais e da borda em escova dos enterócitos do delgado,

A digestão de macronutrientes orgânicos (carboidratos, proteínas e lipídios) é efetuada pelas enzimas do sistema gastrintestinal (SGI) ou sistema digestório (SD). Estas são hidrolases, que catalisam a adição de moléculas de água às ligações $\mathrm{C}-\mathrm{O}$ e C-N dos nutrientes em sítios específicos como representado na sequência: 


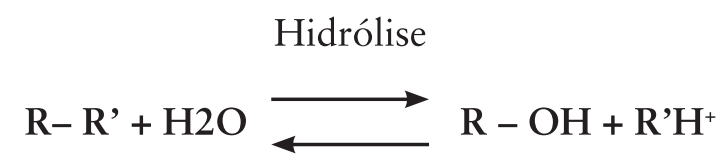

Condensação

O processo de adição de água cinde a molécula dos nutrientes orgânicos em moléculas menores; o processo inverso, de remoção de água, é a condensação.

As enzimas secretadas na luz do SGI denominam-se enzimas luminais e as sintetizadas nas células do SGI, denominadas enterócitos e incorporadas às suas membranas luminais como proteínas integrais, são as enzimas da borda em escova. A meia vida destas enzimas é menor do que a dos enterócitos. Assim, vários ciclos de quebra e síntese das enzimas ocorrem durante a vida destas células. As atividades das enzimas digestivas são facilitadas pelas secreções de água e íons para a luz do TGI (trato gastrointestinal). Resultam dos processos digestivos monômeros, dímeros e trímeros absorvidos através do epitélio do delgado.

Os processos hidrolíticos ocorrem nas várias porções do TGI, na cavidade oral, no estômago e predominantemente no duodeno e nas porções proximais do íleo. O cólon não apresenta enzimas luminais e da borda em escova.

$\mathrm{Na}$ Figura 22.1 estão indicados os locais de secreção das principais enzimas luminais e da borda em escova ao longo do TGI.

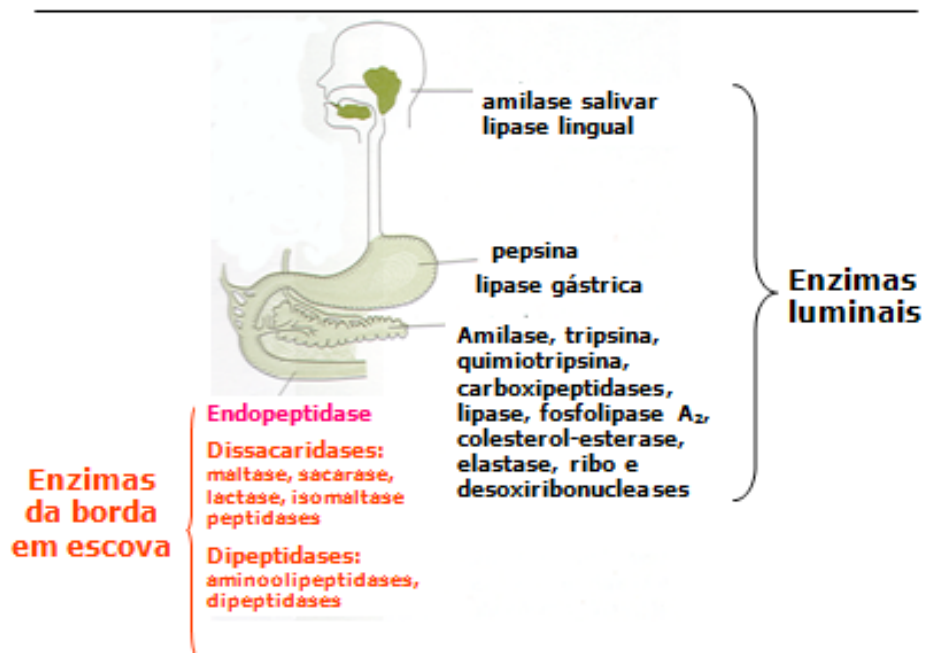

Figura 22.1 - Sítios de secreção das enzimas luminais e localização das enzimas da borda em escova ao longo do trato gastrointestinal. 
A superfície absortiva do delgado é amplificada cerca de 600 vezes, em razão dos graus crescentes de complexidade morfológica. A primeira amplificação se deve às dobras de Kerckring (dobras circulares ou valvulae conniventes). Estas são dobras da mucosa e da submucosa e projetam-se para a luz intestinal com comprimentos de 3 a $10 \mathrm{~mm}$ diminuindo em comprimento e número ao longo do delgado, sendo mais numerosas e maiores no duodeno e no jejuno proximal. Não se submetem a modificações de suas formas com a distensão do intestino. Elevam cerca de 3 vezes a área absortiva do delgado (Figura 22.2).

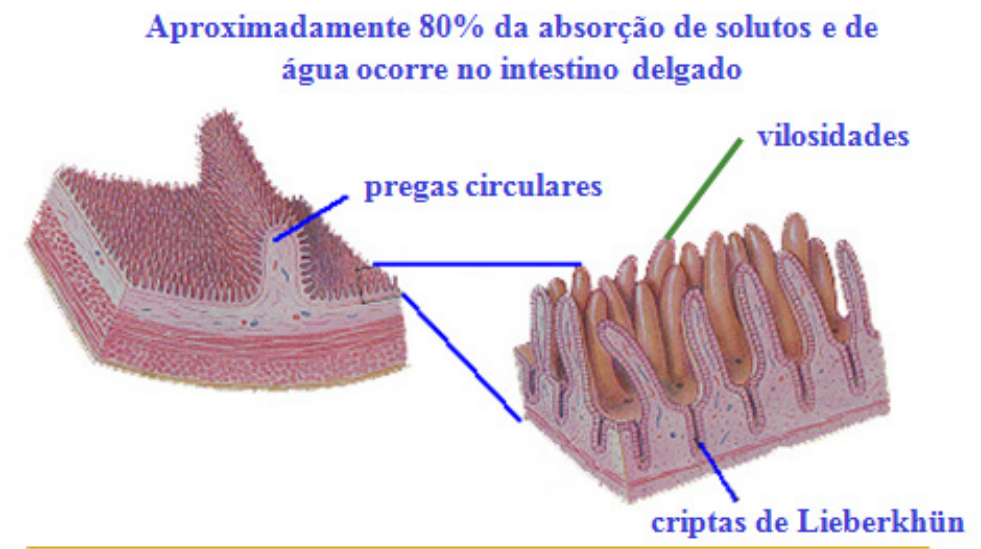

Figura 22.2 - Aumento da superfície absortiva do intestino delgado mostrando as pregas circulares (dobras de Kerckring), as vilosidades e nas suas bases as criptas de Lieberkhün.

O segundo grau de complexidade estrutural no delgado são as vilosidades, que são dobras da mucosa (epitélio, lâmina própria e muscular da mucosa). Seus comprimentos têm cerca de 0,5 a $1,5 \mathrm{~mm}$ e elevam mais cerca de dez vezes a superfície absortiva do delgado. Têm formas foliáceas e digitiformes, embora variem com a distensão do delgado. Diminuem em número e tamanho no delgado no sentido caudal, desaparecendo no cólon.

A arquitetura das vilosidades pode ser modificada por processos de adaptação em resposta à dieta e às demandas fisiológicas, como na lactação ou em resposta à remoção de parte do intestino. Há diminuição do número de vilosidades em várias condições patológicas, formando o que se denomina "mucosa careca".

As bases das vilosidades têm depressões, as chamadas criptas de Lieberkhün, cujas células são indiferenciadas e estão em constantes mitoses. As células nascentes, indiferenciadas, migram para os ápices das vilosidades, diferenciando-se, neste trajeto, em células absortivas ou mucosas. As células das criptas são predominantemente secretoras de água e íons e as do ápice das vilosidades são absortivas e digestivas. 
A membrana luminal (ML) dos enterócitos absortivos apresenta microvilosidades com cerca de $1 \mu \mathrm{m}$ comprimento por $0,1 \mu \mathrm{m}$ de diâmetro, elevando mais cerca de 20 vezes a superfície absortiva. As microvilosidades formam a borda em escova do epitélio intestinal, havendo cerca de 3.000 por célula ou 200 milhões por $\mathrm{mm}^{2}$ de membrana luminal. Assim, o aumento total da área absortiva do delgado, considerando-se os três graus de complexidade morfológica, é igual a 3x 10 x 20, ou seja, 600 vezes superior à área de um cilindro liso de dimensão semelhante à do delgado. Isto equivale a uma área absortiva de 200 a $250 \mathrm{~m}^{2}$, o que corresponde a aproximadamente 100 vezes a área superficial corpórea (Figura 22.3).

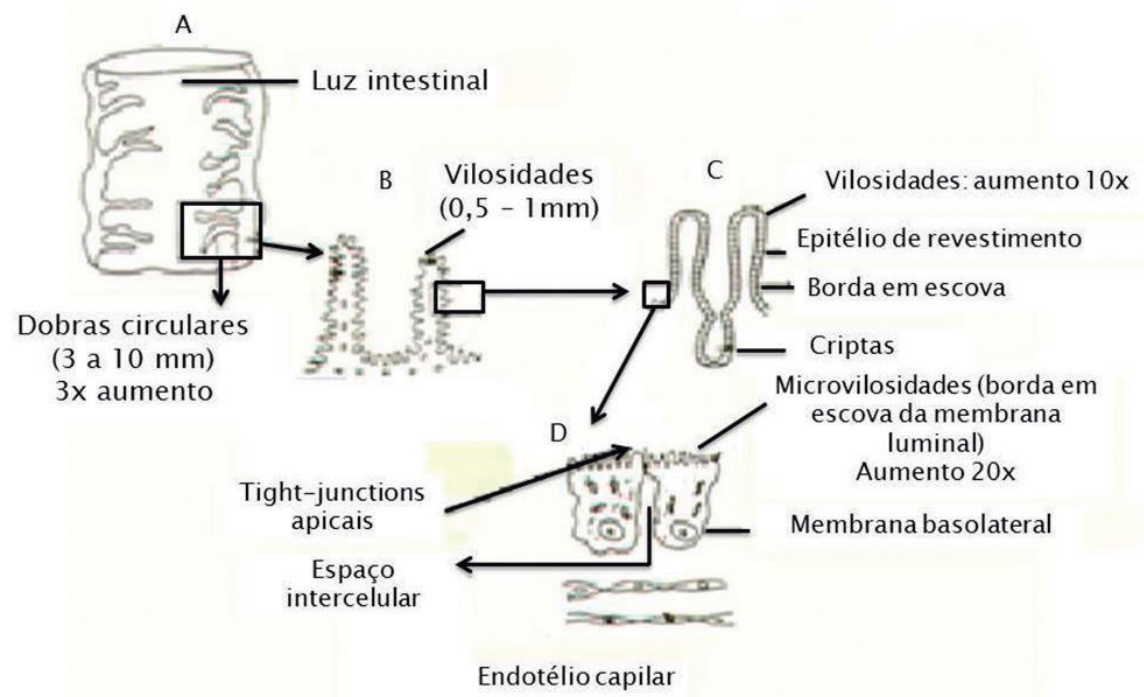

Figura 22.3 - As dobras ou pregas circulares que aumentam a superficie absortiva 3 vezes, em B e C as vilosidades (aumento de dez vezes) e em $D$ as microvilosidades da membrana luminal ou borda em escova (aumento de 20 vezes).

A mucosa duodenal compreende o epitélio, a membrana basal, a lâmina própria e a muscular da mucosa.

O epitélio da mucosa intestinal é monoestratificado e heterocelular contendo as seguintes células: $\mathbf{1}$. absortivas, $\mathbf{2}$. secretoras, 3 . caliciformes, secretoras de muco (globet cells), 4. digestivas contendo enzimas luminais, 5. endócrinas variadas e 6. células $\mathrm{M}$.

A lâmina própria é o tecido conjuntivo de sustentação do epitélio e preenche as vilosidades e as criptas, fazendo contato, de um lado, com a membrana basal do epitélio e, do outro, com a muscular da mucosa. Os tipos celulares mais comuns encontrados na lâmina própria são células mononucleadas como linfócitos, mastócitos, macrófagos e eosinófilos. São comuns, em caso de doenças inflamatórias do intestino, leucócitos polimorfonucleados. 
As células do sistema imunológico do intestino secretam vários parácrinos que regulam processos absortivos e secretores dos enterócitos, como histamina, cininas, metabólitos do ácido araquidônico, prostaglandinas e leucotrienos. São encontrados ainda na lâmina própria, miofibroblastos, fibras colágenas e elásticas, além de fibras nervosas amielínicas do SNE (sistema nervoso entérico) e do SNA (sistema nervoso autônomo).

A membrana basal, sobre a qual repousa o epitélio, é formada por proteoglicanas, fibronecitina, laminina, colágeno e fibroblastos, localizados na face contraluminal da membrana basal. Estas proteínas afetam funções epiteliais como diferenciação celular e transporte de íons e de água. Cerca de 500 poros com 0,5 a $5 \mu \mathrm{m}$ de diâmetro são encontrados na membrana basal de cada vilosidade, o que torna esta membrana bastante permeável às moléculas absorvidas pelos enterócitos e que trafegam entre a lâmina própria e o epitélio.

O epitélio das criptas apresenta os seguintes tipos de células: 1. principais, indiferenciadas, secretoras de água e íons; 2 . absortivas; 3 . mucosas caliciformes (goblet cells); 4. endócrinas variadas; 5 . raras células caveoladas (tuft cells) e 6. células de Paneth, secretoras.

Durante o processo de migração das células, das criptas aos ápices das vilosidades, há aumento de suas atividades enzimáticas e de seus elementos transportadores. Esta migração ocorre com uma velocidade de $10 \mu \mathrm{m} / \mathrm{h}$, levando 3 a 4 dias para as células nascentes alcançarem os ápices das vilosidades, onde substituem as células mais velhas que são descamadas para a luz intestinal. Desta maneira, o epitélio intestinal é completamente renovado a cada 6 a 7 dias. O processo de descamação das células dos ápices das vilosidades fornece cerca de 10 a 25 g de proteínas endógenas por dia. Estas são digeridas e absorvidas como as proteínas exógenas da dieta.

A divisão celular das células das criptas e o seu processo de migração é regulado por fatores tróficos, hormônios gastrointestinais, fatores de crescimento epidérmico e também pela natureza do conteúdo luminal. Como o epitélio do TGI é constantemente renovado, é muito susceptível a agentes quimioterápicos e a radiações.

O cólon não tem enzimas luminais e da borda em escova e absorve apenas água, ions e ácidos graxos voláteis.

O cólon possui diâmetro superior ao do delgado, mas comprimento inferior, de 1,5 m. Estende-se do esfíncter ileocecal ao ânus, apresentando as seguintes diferenciações anátomo-fisiológicas: o ceco, os cólons ascendente, transverso, descendente e o sigmoide que termina no canal retal que se abre para o exterior pelos esfíncteres anais interno e externo. 
O ceco é uma porção dilatada do cólon ascendente e a mais rica em bactérias, apresentando o apêndice vermiforme, uma extensão agregando nódulos linfáticos. O cólon ascendente localiza-se na região ilíaca direita, dirigindo-se para cima e curvando-se à esquerda, formando o cólon transverso, logo abaixo do fígado. O cólon transverso sofre uma inflexão para baixo na região ilíaca esquerda, formando o cólon descendente que é a porção mais estreita do cólon. Sua posição é retroperitoneal e origina, na região pélvica, o cólon sigmoide, cuja forma resulta da contração tônica do músculo puborretal inervado pelo nervo pudendo. $\mathrm{Na}$ altura da terceira vértebra sacral inicia-se o reto e, na sua porção mais distal, forma o canal retal que se abre no ânus.

As características estruturais do cólon são: 1. presença das Taenia coli, que são espessamentos da musculatura longitudinal formando quatro feixes, abaixo dos quais localizam-se os plexos mioentéricos; 2 . a ausência de vilosidades, mas existência das microvilosidades formando a borda em escova; 3. grande número de células caliciformes mucosas superficiais no seu epitélio e 4. grande número de linfócitos e nódulos linfáticos na submucosa.

As características fisiológicas importantes do cólon, distintas das do delgado, são: 1 ausência de enzimas luminais e da borda em escova; 2. absorção apenas de água e íons, em quantidades muito inferiores às que ocorrem no delgado e 3. presença de bactérias residentes. O cólon é capaz de absorver produtos orgânicos como os derivados da fermentação bacteriana, e ácidos graxos de cadeias curtas (ácidos graxos voláteis) resultantes predominantemente de carboidratos não digeridos e não absorvidos no delgado.

Tanto os enterócitos como os colonócitos são células prismáticas, altas, com o núcleo ovoide basal, sistema de Golgi para e supranuclear, retículo endoplasmático bastante desenvolvido, microtúbulos e microfilamentos, lisossomas com estruturas relacionadas como corpos multivesiculares, e peroxisomas.

São muitas as barreiras que devem ser transpostas para a absorção de substâncias da luz intestinal até os capilares. 


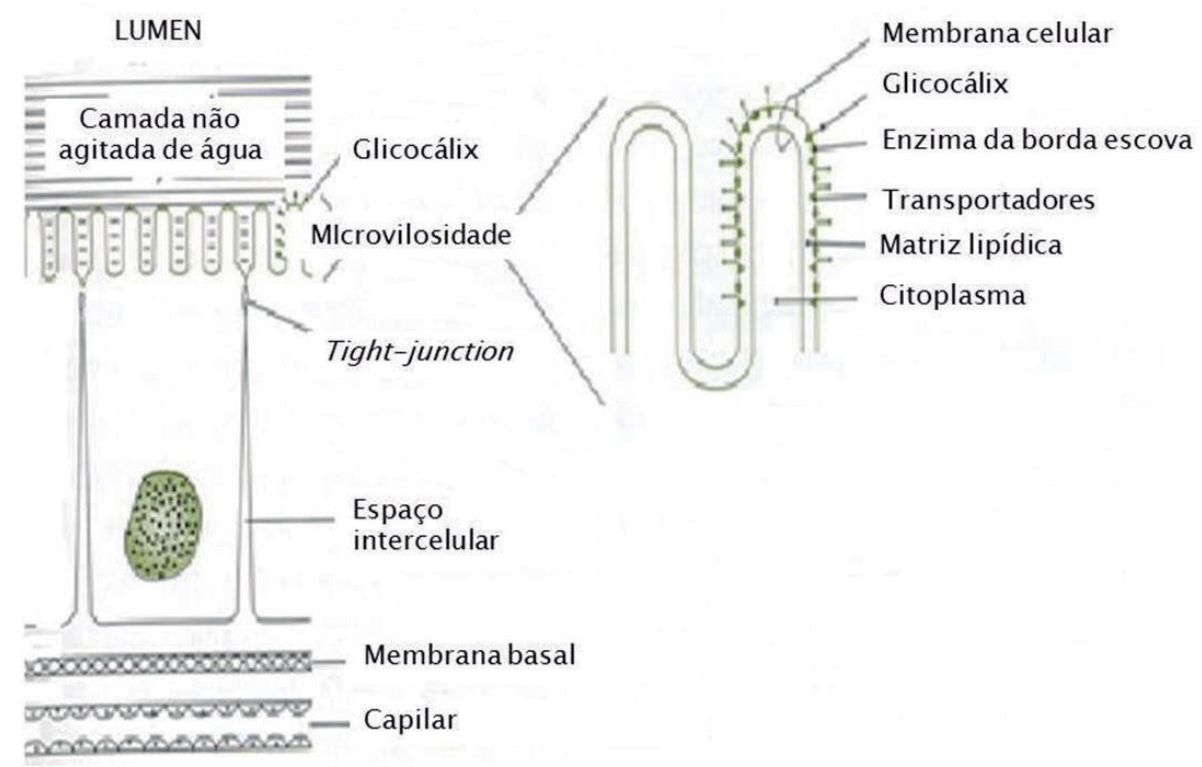

Figura 22.4 - As barreiras epiteliais absortivas intestinais. Adaptada de Johnson L.R. In Gastrointestinal Physiology, The Mosby Physiology Monograph Series, $6^{\text {th }}$ Ed, 2001.

1. A camada de água não agitada que recobre a borda em escova. Sua espessura é de 200 a $500 \mu \mathrm{m}$ e é a principal barreira para a absorção dos produtos da hidrólise lipídica. 2. O glicocálix. 3. A estrutura lipoproteica da membrana luminal ou borda em escova das células absortivas. 4. O citosol, se a absorção for transcelular; se for intercelular, as tight-junctions apicais e os espaços intercelulares. 5. A membrana basolateral das células absortivas. 6. O endotélio capilar. Estas barreiras estão esquematizadas na Figura 22.4.

\section{O epitélio intestinal diferencia-se eletrofisiologicamente no sentido cefa- locaudal. \\ O compartimento luminal é negativo em relação ao intersticial. Esta diferen- ça de potencial elétrico decorre dos distintos mecanismos de transporte de íons nas duas membranas em série das células epiteliais, a membrana luminal (ML) e a membrana basolateral (MBL) e da contribuição das tight-junctions (TJ). que são os elementos estruturais mais apicais dos complexos juncionais intercelulares que mantêm as células epiteliais coesas. Abaixo estão comparadas as razões entre as resistências elétricas das membranas celulares (MC) e as das “tight-junctions" (TJ) apicais intercelulares no intestino delgado e no cólon.}

$$
\mathbf{R}_{M C} / \mathbf{R}_{\mathrm{TJ}}=\mathbf{2 0} \text { no delgado, e }
$$

$$
\mathbf{R}_{\mathrm{MC}} / \mathbf{R}_{\mathrm{TJ}} \sim 1 \text { no cólon. }
$$


Isto significa que a resistência das MC no delgado é 20 vezes superior à das TJ, enquanto no cólon, a resistência das TJ é quase tão alta quanto à das MC. Por este motivo, o epitélio do delgado é classificado como epitélio do tipo leaky e o do cólon do tipo tight. Como consequência, há, assim, um gradiente decrescente de permeabilidade iônica (ou de condutividade iônica) intercelular, no sentido cefalocaudal no intestino refletindo o aumento de resistência elétrica (ou diminuição da condutância elétrica) da via intercelular. Assim, no delgado, os fluxos iônicos intercelulares contribuem de maneira mais significativa aos fluxos transepiteliais totais do que no cólon.

Decorrem desta diferença várias características de transporte nos epitélios. Como as TJ funcionam como uma via de "shunt" ou de curto-circuito do transporte transcelular de cargas elétricas ou íons, quanto maior for a resistência das TJ, menor é o curto-circuito e maior a diferença de potencial elétrico transepitelial ou $\mathrm{DP}_{\text {trans }}$. Assim, a magnitude da $\mathrm{DP}_{\text {trans }}$ eleva-se gradativamente no sentido cefalocaudal, alcançando no cólon valores entre -30 a $-50 \mathrm{mV}$, a luz negativa, em relação ao compartimento intersticial-vascular. No delgado, a via de "shunt" é muito condutiva (ou pouco resistiva), representando quase $95 \%$ da condutância total do epitélio; no cólon, assim a contribuição da via de "shunt" à condutância transepitelial total é menor, de 60 a $80 \%$.

Na Figura 22.5 estão representados os principais mecanismos de transporte de um epitélio do tipo tight, no qual o influxo de $\mathrm{Na}^{+}$do meio luminal para o intracelular ocorre de maneira desacoplada ou eletrogênica, por mecanismo de eletrodifusão via canais epiteliais para $\mathrm{Na}^{+}$, bloqueáveis por amiloride. Estes canais epiteliais para o $\mathrm{Na}^{+}(\mathrm{ENaC})$ já foram clonados no cólon de mamíferos. A $\mathrm{Na}^{+} / \mathrm{K}^{+} \mathrm{ATPase}$, eletrogênica (ou reogênica) é mostrada em círculo escuro nas MBL onde também está representado um canal para $\mathrm{K}^{+}$. As vias de transporte transcelular, por via das duas membranas em série e da via intercelular estão também esquematizadas.

$\mathrm{Na}$ base da figura está representado o perfil de potencial elétrico através do epitélio. Tomando-se, como referencial, o potencial luminal, como zero, a célula é negativa tanto em relação à luz como em relação ao interstício. $\mathrm{O}$ potencial elétrico do interstício é superior ao da célula e ao da luz. A $\mathrm{DP}_{\text {trans }}$ é a diferença entre o potencial elétrico entre a luz intestinal e o interstício. 


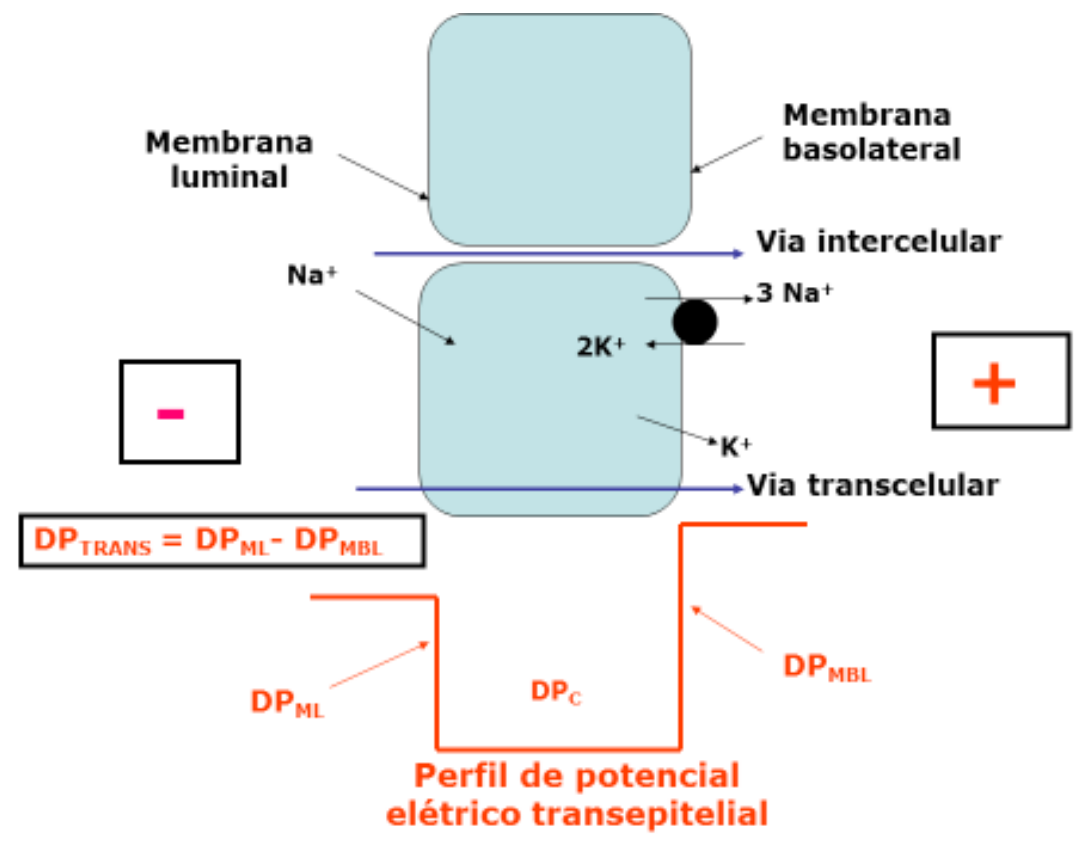

Figura 22.5 - Esquema dos principais processos de transporte através de epitélio do tipo "tight": a via transcelular de transporte e a via intercelular. A parte inferior do esquema representa o perfil de potencial elétrico transepitelial DP ${ }_{\text {transs }}$ sendo esta a diferença entre a DP da membrana celular, a membrana luminal (ML) e a basolateral (MBL). 0 compartimento luminal é negativo e o intersticial positivo. 0 compartimento intracelular é mais negativo do que os compartimentos luminal e intersticial.

Fatores exógenos induzem alterações adaptativas dos processos digestivos e absortivos.

Ocorrem alterações dos processos digestivos e/ou absortivos do intestino induzidas por fatores externos, como modificações da dieta, ressecções cirúrgicas de porções do intestino. Tais modificações permitem ao organismo um ajuste no sentido de manter a homeostase e são, adaptativas. Alterações da dieta levam também a adaptações do padrão enzimático. Estas adaptações refletem alterações na síntese das enzimas e são pouco compreendidas.

Remoções cirúrgicas de porções do delgado levam, após um período, a adaptações dos processos digestivos e absortivos, acompanhados de hiperplasia dos segmentos restantes do intestino. Remoção do íleo, entretanto, leva a defeitos não compensados na absorção da vitamina $\mathrm{B}_{12}$ e na dos sais biliares.

Adaptações decorrentes do processo de desenvolvimento são muito estudadas em ratos. Nestes animais, os níveis das dissacaridases da borda em escova, exceto o da lactase, são muito baixos no recém-nascido. Após o desmame, a atividade das dissacaridases da borda em escova eleva-se, enquanto a da lactase diminui, podendo desaparecer na idade adulta. Estas alterações, 
que acompanham o desenvolvimento do indivíduo são geneticamente programadas.

Em humanos há pouca informação sobre alterações enzimáticas relacionadas com o desenvolvimento. As dissacaridases estão no nascimento e não diminuem com a idade, com exceção da lactase. Esta enzima é mais elevada no recém-nascido do que no adulto, e em muitos adultos ela diminui ou desaparece.

\section{RESUMO}

1. Digestão e absorção dos nutrientes orgânicos ocorrem predominantemente no duodeno e nas porções proximais do jejuno. A digestão é efetuada por enzimas lançadas na luz intestinal, enzimas luminais, e pelas enzimas da borda em escova, proteínas integrais da ML dos enterócitos.

2. O íleo absorve vitamina $B_{12}$ e a grande parte dos sais biliares. $O$ cólon não possui enzimas e absorve água, íons, produtos da fermentação bacteriana e ácidos graxos voláteis.

3. A área absortiva do delgado é grandemente amplificada pelas dobras circulares, vilosidades e microvilosidades (borda em escova) sendo cerca de 100 vezes superior à área corpórea superficial.

4. As células dos ápices das vilosidades do delgado e das porções mais superficiais do cólon são absortivas. As células das criptas são predominantemente secretoras.

5. As células das criptas são indiferenciadas e estão em constantes mitoses gerando células que migram para os ápices das vilosidades substituindo-as a cada 6 a 7 dias.

6. As barreiras epiteliais que as substâncias absorvidas atravessam são a camada não agitada de água, o glicocálix, a ML, o citosol, as tight-junctions (TJ), os espaços intercelulares, a MBL e a membrana basal do epitélio.

7. O epitélio intestinal apresenta um gradiente decrescente de condutividade iônica das TJ no sentido cefalocaudal. O duodeno é mais "leaky" do que o jejuno, este mais do que o íleo, sendo o cólon um epitélio "tight”. Por este motivo, a $\mathrm{DP}_{\text {trans }}$ aumenta no mesmo sentido.

8. As vias intercelulares contribuem significantemente para a absorção no delgado, e menos no cólon. 


\subsection{DIGESTÃO E ABSORC̣ÃO DE CARBOIDRATOS}

A quantidade de carboidratos da dieta humana é por demais variável sendo função de fatores culturais, geográficos e nível socioeconômico das populações. Seu consumo varia inversamente com o seu poder aquisitivo.

A proporção relativa de carboidratos da dieta humana, recomendada pela Organização Mundial de Saúde e pelo Comitê Americano de Nutrição, é de 58\%, mas a proporção efetivamente utilizada na dieta das populações de países desenvolvidos é de $50 \%$, o que representa de 300 a 500 g/dia. Como os carboidratos, quando totalmente degradados a $\mathrm{CO}_{2}$ e água fornecem $4 \mathrm{kcal}$, uma ingestão de 300 a $500 \mathrm{~g} /$ dia representa 1.200 a $2.000 \mathrm{kcal} / \mathrm{dia}$.

Os principais carboidratos e suas proporções relativas na dieta humana ocidental.

$\mathrm{Na}$ Tabela 22.1 estão representados os principais carboidratos e suas proporções relativas na dieta humana ocidental.

\section{Tabela 22.1 - Principais carboidratos e suas proporçoes relativas (em \%) na diefa humana ocidental}

\begin{tabular}{|lc|}
\hline Amido (grãos e cereais): unidades de glicose & 50 \\
\hline Sacarose (cana de açúcar): glicose + frutose & 30 \\
\hline Lactose (leite e derivados): glicose + galactose & 10 \\
\hline Maltose (malte): glicose + glicose & 2 \\
\hline Glicogênio de origem animal: unidades de glicose & quantidades varíveis \\
\hline Celulose e pectinas (vegetais) & quantidades varíaveis \\
\hline
\end{tabular}

$\mathrm{O}$ amido é um polímero de glicose com $\mathrm{PM}>100 \mathrm{Kd}$, encontrado em grãos e tubérculos de origem vegetal. É formado por cadeias retilíneas de amilose com $\mathrm{PM}<10^{6}$, com ligações $\alpha$ [1-4]-glicosídicas e de cadeias ramificadas de amilopectina com PM $>10^{6}$, com ligações $\alpha$ [1-6]-glicosídicas. A amilose representa $20 \%$ da molécula de amido com aproximadamente 25 a 2.000 monômeros de glicose. A amilopectina representa $80-90 \%$ da molécula do amido com 6.000 ou mais monômeros de glicose. O glicogênio é um polissacarídeo semelhante à amilopectina, de origem animal e com um número maior de ramificações e de 
monômeros de glicose, de 1.700 a 22.000 ou mais (Figura 22.6). A celulose, de origem vegetal, é um polissacarídeo com cerca de 2.500 moléculas de glicose em cadeia retilínea, mas com ligações $\beta$ [1-4]. A celulose, hemicelulose e as pectinas não são hidrolisadas em humanos e representam as fibras.

\section{CADEIAS RETAS DE AMILOSE: LIGAÇÕES ALFA-1-4-GLICOSÍdICAS}

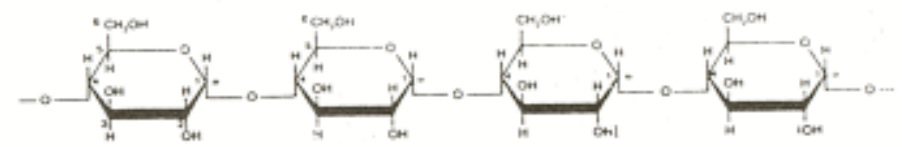

(a)
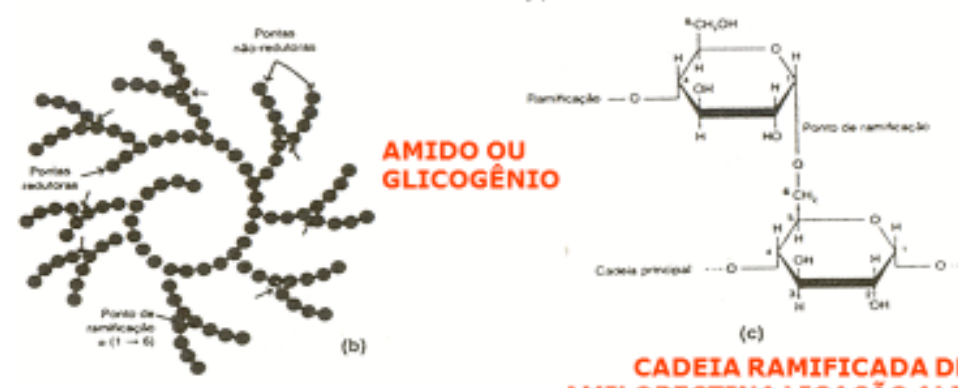

(c)

CADEIA RAMIFICADA DE AMILOPECTINA LIGAÇẢO ALFA-1-6

Figura 22.6 - Estruturas químicas das cadeias retas de amilose (a) do amido ou glicogênio (b) da cadeia ramificada da amilopectina (c).

A digestão dos carboidratos inicia-se na boca e continua-se no delgado pela $\alpha$-amilase e pelas enzimas da borda em escova.

A $\alpha$-amilase salivar ou ptialina é muito semelhante à pancreática. Difere desta, porém, pelo fato de que a ptialina não é capaz de romper a camada de celulose que recobre o amido cru, agindo apenas sobre o amido cozido. Ambas atuam na mesma faixa de $\mathrm{pH}$, entre quatro e onze, sendo o pH ótimo da ação hidrolítica 6,9 , tendo o $\mathrm{Cl}^{-}$como cofator da ação hidrolítica. Valores de $\mathrm{pH}$ menores do que 4,0 inativam as $\alpha$-amilases. Como o alimento permanece pouco tempo na cavidade oral, a hidrólise do amido ingerido, nesta porção do TGI, é de apenas 3 a $5 \%$.

As duas $\alpha$-amilases são endoamilases, ou seja, elas hidrolisam ligações glicosídicas no interior das cadeias polissacarídicas e apenas ligações $\alpha$ [1-4]- glicosídicas. Assim não resultam de suas ações hidrolíticas, monômeros ou hexoses.

A digestão do amido continua no estômago, durante quase uma hora, na fase de armazenamento, em que o alimento ainda não foi submetido à ação de mistura pelas peristalses gástricas. No interior do estômago, a $\alpha$-amilase salivar 
pode hidrolisar até $75 \%$ do amido ingerido, resultando os dissacarídeos, maltose, maltotriose e $\alpha$-limite dextrina que são os mesmos oligossarídeos com ligações $\alpha[1-6]$-glicosídicas, contendo de seis a nove moléculas de glicose.

No intestino delgado, a $\alpha$-amilase pancreática é secretada na forma de enzima ativa, em concentração elevada possuindo, também, alta atividade catalítica: $1 \mathrm{ml}$ de suco duodenal é capaz de hidrolisar 1 a $9 \mathrm{~g}$ do amido por hora. Assim, dezminutos após a chegada do quimo ao duodeno, o amido é completamente hidrolisado. A hidrólise final dos di e trissacarídeos e da $\alpha$-limite dextrina é efetuada pelas oligossacaridases da borda em escova: maltase (ou glicoamilase), lactase, sacarase, $\alpha$-dextrinase (ou isomaltase) e trealase. Assim, a digestão final dos polissacarídeos é efetuada por estas enzimas da membrana luminal.

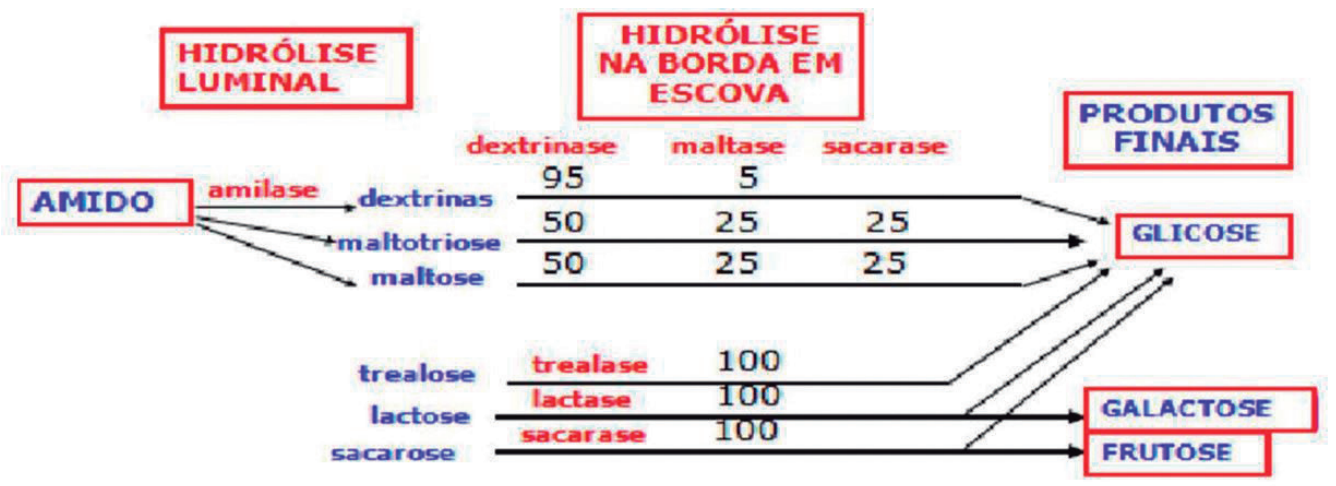

Figura 22.7 - 0s produtos intermediários da hidrólise de polissacarídeos (glicogênio ou amido) pelas $\alpha$-amilases lumiais (salivar e pancreática) e pelas enzimas da borda em escova intestinal e os produtos finais destas hidrólises.

A Figura 22.7 ilustra a hidrólise dos polissacarídeos tanto pelas enzimas luminais, as $\alpha$-amilases salivar e pancreática, como pelas enzimas da borda em escova, maltase, dextrinase, lactase, sacarase, trealase e glicoamilase.

As enzimas da borda em escova têm especificidades para vários substratos. Assim, as $\alpha$-dextrinases hidrolisam quase $95 \%$ das $\alpha$-limite dextrinas que também podem ser hidrolisadas (cerca de $5 \%$ ) pela maltase, embora apenas as $\alpha$-dextrinases hidrolisem as ligações $\alpha$ [1-6]-glicosídicas. A maltotriose pode ser hidrolisada tanto pela $\alpha$-dextrinase $(50 \%)$ como pela maltase $(25 \%)$ e pela sacarase $(25 \%)$. As mesmas enzimas hidrolisam a maltose em proporções similares. As enzimas da borda em escova com especificidade para os seus substratos são a lactase e a trealase. Lactose, trealose e sacarose são 100\% hidrolisadas, respectivamente, pelas lactase, trealase e sacarase. Os produtos finais da digestão dos carboidratos pelas enzimas luminais e da borda em escova são glicose, cerca de 70 a $80 \%$, frutose, cerca de $15 \%$ e galactose, cerca de $5 \%$ (Figura 22.7). 


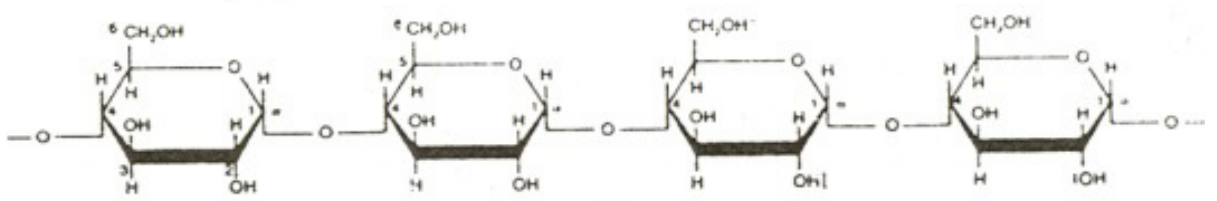

(a)
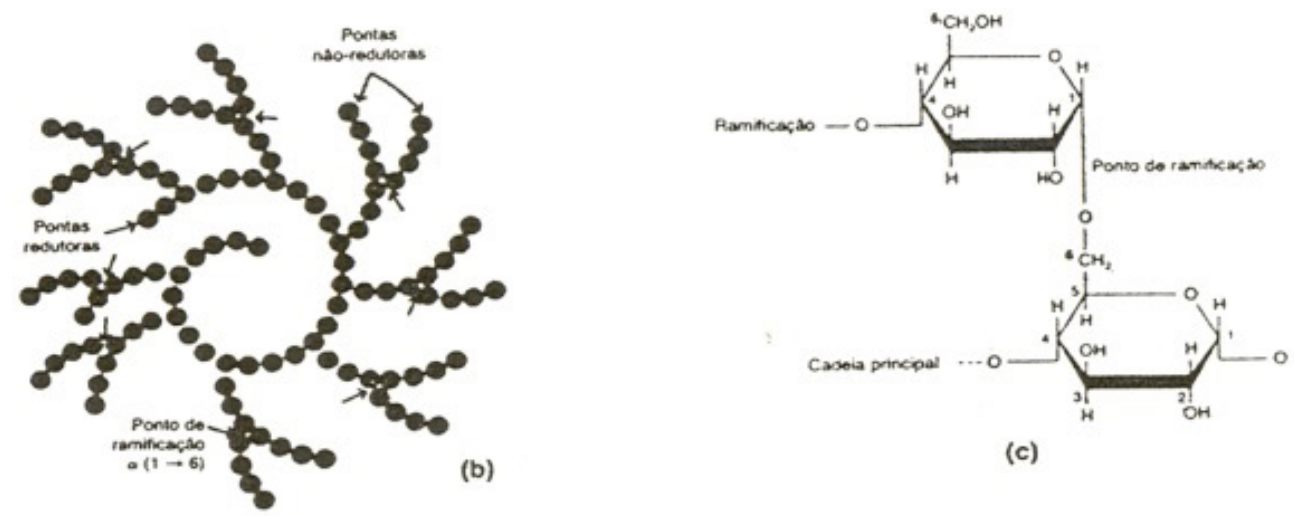

(c)

Figura 22.8 - Esquema indicando a cadeia reta de amilose com ligações [alfa-1-4]-glicosídicas (a); a estrutura do amido ou glicogênio, sendo cada círculo um monômero de glicose (b) e a cadeia ramificada da amilopectina com ligações [alfa-1-6]-glicosídicas (c).

As atividades das enzimas da borda em escova são mais elevadas no duodeno e jejuno proximal, decaindo no sentido cefalocaudal ao longo do delgado. Isto significa que a digestão dos carboidratos completa-se já no jejuno proximal. As oligossacaridases da borda em escova são afetadas tanto por fatores exógenos, genéticos, assim como por alterações da dieta.

Nas populações não caucasianas, como negros e asiáticos, assim como, em vários outros mamíferos, ocorre, com frequência bastante elevada, uma diminuição ou mesmo um desaparecimento da atividade da lactase após o desmame. Estas alterações são programadas geneticamente, causando a condição patológica conhecida como intolerância à lactose que pode ser congênita aparecendo no recém-nascido.

Crônica ingestão de sacarose ou ausência de sua ingestão afeta grandemente a atividade da sacarase. Por outro lado, a atividade da lactase é mais resistente às alterações da dieta do que a sacarase, mas é muito mais sensível do que as outras oligossacaridases às injúrias dos enterócitos.

Como há grande reserva de $\alpha$-amilase pancreática e de dissacaridases na borda em escova, o passo limitante para o aproveitamento ou assimilação dos carboidratos da dieta não é o processo digestivo, mas a absorção das hexoses que, 
em condições normais e efetua no duodeno e jejuno proximal, decaindo no jejuno distal e no íleo.

Os produtos finais da digestão dos carboidratos, glicose, galactose e frutose são absorvidos em duas etapas mediados por carregadores nas duas membranas dos enterócitos.

Como as hexoses não permeiam facilmente a bicamada lipídica das membranas celulares dos enterócitos, elas são transportadas por carregadores específicos. $\mathrm{Na}$ membrana luminal (ML), a glicose e a galactose são transportadas ativamente

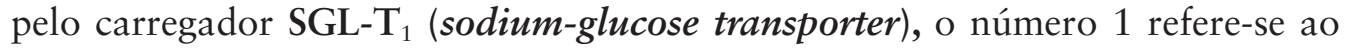
fato deste carregador de hexoses ter sido o primeiro descrito. Há um acoplamento do influxo de $1 \mathrm{~mol}$ glicose (ou de galactose) a 2 moles de $\mathrm{Na}^{+}$. Este, portanto, é um cotransportador $2 \mathrm{Na}^{+}$: glicose ou galactose, eletrogênico, que depende tanto do gradiente eletroquímico para o $\mathrm{Na}^{+}$através da $\mathrm{ML}$, mantido pela $\mathrm{Na}^{+} / \mathrm{K}^{+}$ATPase da MBL, como do potencial elétrico da ML. Assim, a absorção intestinal de glicose e de galactose através da ML é um transporte ativo secundário acoplado ao influxo de $\mathrm{Na}^{+}$. Inibição da $\mathrm{Na}^{+} / \mathrm{K}^{+}$- ATPase inibe a absorção intestinal de glicose e/ou galactose porque dissipa o gradiente de potencial eletroquímico para o $\mathrm{Na}^{+}$através da célula. Além disso, a redução de $\mathrm{Na}^{+}$luminal ou a sua ausência afetam também a absorção intestinal destas hexoses, porque diminui a afinidade do SGL-T 1 para a glicose e/ou galactose. Na MBL, a glicose e a galactose, são transportadas passivamente por difusão facilitada mediada pelo carregador pertencente à família dos GLUTs, no caso, o GLUT 2 que também transporta frutose através desta membrana. A frutose é transportada através da ML por difusão facilitada, independente de acoplamento com o $\mathrm{Na}^{+}$e mediada pelo GLUT 5. Os mecanismos de absorção das hexoses nas duas membranas dos enterócitos estão na Figura 22.9. 


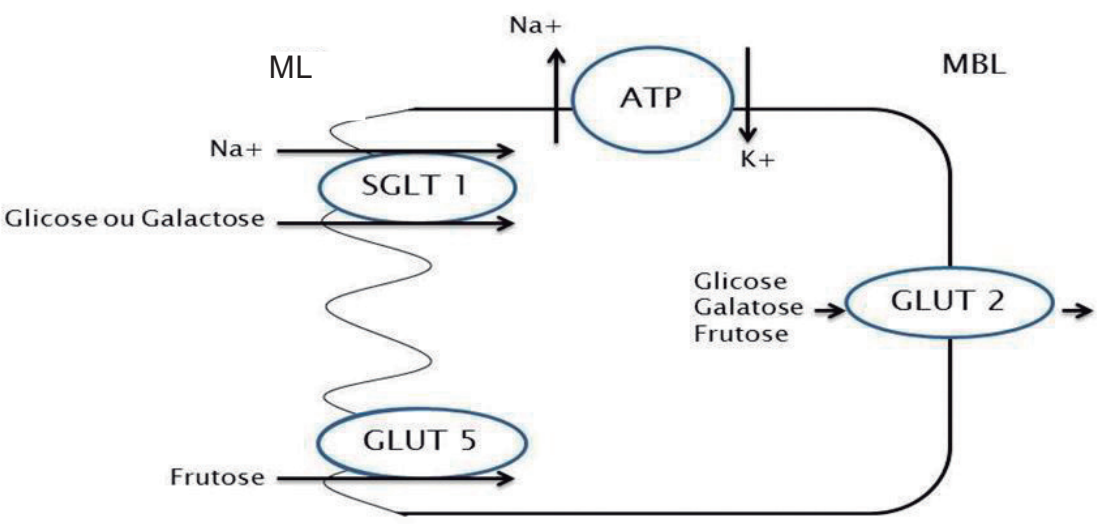

Figura 22.9 - Mecanismos de absorção de glicose, galactose e frutose nas duas membranas das células do delgado, a membrana luminal (ML) e a membrana basolateral (MBL). Os produtos finais da digestão dos carboidratos, glicose, galactose e frutose são absorvidos em duas etapas mediados por carregadores nas duas membranas dos enterócitos.

O cotransportador $2 \mathrm{Na}^{+}$: glicose ou galactose e as várias isoformas dos GLUTs (transportadores de glicose) já foram sequenciados e clonados. A especificidade SGL- $T_{1}$ é penas para as formas $\mathrm{D}$ e para as hexoses que possuem o anel piranose. A Figura $\mathbf{2 2 . 1 0}$ mostra a estrutura do transportador de glicose/galactose da membrana luminal do enterócito do delgado.

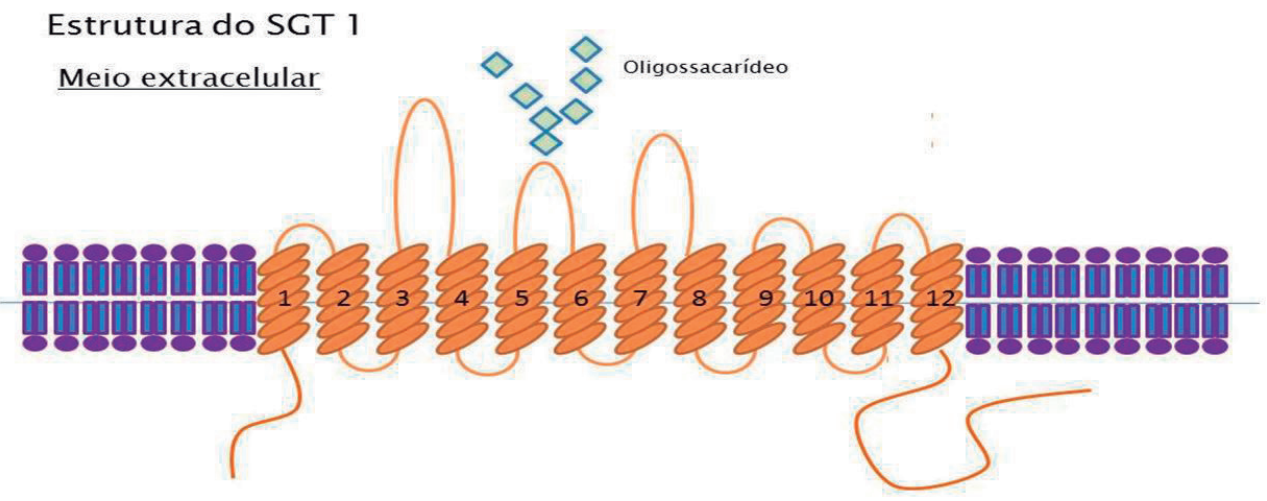

Figura 22.10 - Transportador de glicose e/ou galactose através da membrana luminal dos enterócitos. Esta proteína apresenta 12 domínios intramebrânicos. Seu PM é cerca e $73 \mathrm{kDa}$ e é especifico para o transporte de hexose que tem conformação $\mathrm{D}$ e anel piranose como na figura em que 0 anel é 0 da D-glicose. 0 anel da D-galactose tem $0 \mathrm{H} \mathrm{e} 0 \mathrm{OH}$ no carbono 4 invertidos (adaptado do livro de Mediacal Physiology, Boron WF e Boulpaep EL, updated ed., 2005, figura 44-4, pag. 952). 
A absorção de hexoses diretamente ingeridas ou provenientes de dissacarídeos ocorre mais rapidamente e se completa totalmente até o jejuno proximal; entretanto, as taxas e os sítios de absorção de hexoses provenientes do amido variam conforme o tipo de alimento e certa quantidade não é absorvida. Esta quantidade é cerca de $6 \%$ a $10 \%$ de uma refeição contendo 20 a 60 g de amido. Os carboidratos não absorvidos no delgado servem de fonte de carbono para as bactérias colônicas.

Há grande variação nos índices glicêmicos de pessoas normais, medidos após a ingestão dos diversos tipos de alimento contendo amido. Esta variação pode ser aferida pelo índice glicêmico é o valor da quantidade de glicose sanguínea após a ingestão de uma determinada quantidade de alimento contendo amido, comparativamente à quantidade de glicose sanguínea $2 \mathrm{~h}$ após a sua ingestão.

Como há grande reserva de alfa-amilase pancreática e de dissacaridases na borda em escova, o passo limitante para o aproveitamento dos carboidratos da dieta não é o processo digestivo, mas sim a absorção das hexoses que, em condições normais, efetua-se no jejuno proximal, decaindo no jejuno distal e no íleo.

\section{FISIOPATOLOGIA}

Deficiência de sacarase-isomaltose (dextrinase). É uma doença hereditária autossômica recessiva, caracterizada por baixos níveis de atividade destas enzimas da borda em escova resultando intolerância à sacarose e ao amido. Estas duas enzimas são subunidades da mesma proteína, associadas não covalentemente. A doença é descrita em $10 \%$ dos esquimós e em cerca de 0,2\% em norte-americanos. Os pacientes recebem dietas com baixo conteúdo de amido e sacarose.

Síndrorme de má absorção de glicose e galactose. É uma doença de origem genética, bastante rara, em consequência de múltiplas mutações que resultam em substituição de um único aminoácido do cotrasportador $2 \mathrm{Na}^{+}$: glicose ou galactose (SGLT-1). Cada uma destas substituições induz alterações que previnem o transporte de glicose e/ou de galactose nos indivíduos afetados. Os pacientes apresentam diarreia osmótica em consequência da má-absorção das hexoses e de $\mathrm{Na}^{+}$. Neste caso, a dieta não deve conter amido, glicose ou galactose. A frutose é bem tolerada. As outras dissacaridases da borda em escova não são afetadas. Os pacientes não apresentam glicosúria, uma vez que o túbulo proximal do néfron possui as isoformas SGLT-1 e SGLT-2, ocorrendo, assim, reabsorção tubular normal de glicose no rim. 
Intolerância à lactose. Pode ser congênita, acometendo recém-nascidos, ou ser programada geneticamente, induzindo diminuição ou desaparecimento total da lactase da borda em escova após o desmame. Predomina em negros e asiáticos, ocorrendo em menor proporção nas populações brancas. Sua frequência é alta na população brasileira devido à miscigenação. Como a lactase não é digerida, ela pemanece na luz intestinal, podendo causar um espectro de sintomas como: diarreia osmótica, distensão abdominal e cólicas.

\section{RESUMO}

1. O amido, a sacarose (açúcar da cana) e a lactose (açúcar do leite e derivados) são os carboidratos mais frequentes da dieta humana.

2. Quando totalmente degradados a $\mathrm{CO}_{2}$ e água, $1 \mathrm{~g}$ de carboidrato fornece 4 $\mathrm{kcal}$. São ingeridos cerca de 300 a $500 \mathrm{~g} / \mathrm{dia}$, o que representa o fornecimento de 1.200 a $1.300 \mathrm{kcal} / \mathrm{dia}$.

3. Na cavidade oral são hidrolisados 3-5\% e no estômago, antes da mistura do quimo, aproximadamente $75 \%$ pela $\alpha$-amilase salivar. No delgado a $\alpha$-amilase pancreática e as oligossacaridases da borda em escova terminam a digestão dos carboidratos resultando glicose $(\sim 80 \%)$, galactose $(\sim 5 \%)$ e frutose $(\sim 15 \%)$.

4. Glicose e galactose são absorvidas por transporte ativo secundário eletrogênico mediado pelo cotransportador SGL-T ${ }_{1}$ da ML que acopla o transporte das hexoses a 2 íons $\mathrm{Na}^{+}$. A frutose é absorvida passivamente pelo GLUT5 na ML. Na MBL as hexoses são absorvidas por GLUT2, passivamente.

5. A intolerância à lactose na idade adulta é a patologia mais frequentemente observada.

\subsection{DIGESTÃO E ABSORC̣ÃO DE PROTÉ́NAS}

Todas as proteinas contidas no TGI são digeridas e absorvidas.

A quantidade de proteína na dieta, para manter o balanço nitrogenado, varia extremamente com fatores socioeconômicos da população. Nas populações de países desenvolvidos, são ingeridos entre 70 e $100 \mathrm{~g}$ de proteínas por dia, uma quantidade excessiva relativamente às necessidades do organismo e representa 10 a $15 \%$ da ingestão calórica. Nas populações pobres, a ingestão proteica é em média de $50 \mathrm{~g}$ por dia. Nestas populações, as crianças, cujo requisito proteico é maior do que nos adultos, ingerem frequentemente cerca de $4 \mathrm{~g}$ de proteína por dia, sendo, assim, as mais afetadas.

As proteínas ingeridas originam-se de carnes e de vegetais. Os processos digestivos e absortivos das proteínas são muito eficientes, praticamente todas as proteínas ingeridas e as contidas no TGI são completamente hidrolisadas e absorvidas em condições normais. São excretados nas fezes apenas 1 a $2 \mathrm{~g}$ de nitrogênio por dia, correspondente a 6 a $12 \mathrm{~g}$ de proteína. 
São encontradas de 35 a 200 g por dia de proteínas endógenas na luz do TGI. Estas resultam das secreções salivar, gástrica, pancreática, biliar e intestinal e são enzimas, hormônios e imunoglobulinas e do muco além das originárias da descamação das células da parede do TGI e algumas proteínas plasmáticas que podem ter entrado na luz do TGI. Todas são hidrolisadas e absorvidas como as da dieta. As proteínas encontradas nas fezes são originárias do cólon, de células descamadas, do muco, e principalmente, de proteínas derivadas de origem bacteriana (Quadro 22.1).

\section{Quadro 22.1 - Proteínas contidas na luz do TGI.}

Proteínas exógenas da dieta (quantidade recomendada para manter o balanço nitrogenado de 70 a $100 \mathrm{~g} / \mathrm{dia}$ ).

Proteínas endógenas originadas de células descamadas e de bactérias na luz do TGl: quantidade de 35 a 200g/dia.

Nas fezes são encontradas proteínas originárias do cólon: 6 a $12 \mathrm{~g}$ de proteína/dia ou 1 a $2 \mathrm{~g}$ de $\mathrm{N}$.

Os processos digestivos e absortivos são altamente eficientes no delgado. $1 \mathrm{~g}$ de proteína fornece $4 \mathrm{Kcal}$.

Os principais processos digestivos e absortivos das proteínas ocorrem no duodeno e no jejuno proximal. Até o jejuno distal, todos os produtos da hidrólise das proteínas foram absorvidos.

As enzimas luminais de origem gástrica e pancreática originam oligopeptídeos e aminoácidos livres.

Os processos da digestão proteica luminal podem ser divididos nas fases gástrica e intestinal (ou pancreática), segundo os sítios de origem das enzimas proteolíticas.

$\mathrm{Na}$ fase gástrica, a hidrólise ocorre pelas pepsinas e pelo $\mathrm{HCl}$ que confere um pH adequado para a ativação do pepsinogênio a pepsina. A ativação ocorre pela remoção de 44 aminoácidos da terminação $\mathrm{NH}_{2}$ do pepsinogênio ou pró-enzima. A clivagem entre os resíduos 44 e 45 do pepsinogênio ocorre via reação intramolecular (autoativação) mais lentamente a valores de $\mathrm{pH}$ de três a cinco e muito rapidamente a $\mathrm{pH}<3$. A pepsina ativada efetua autocatálise e a atividade máxima da pepsina ocorre entre valores de $\mathrm{pH} 1,8$ a 3,5, ou seja, no estômago secretando maximamente durante a fase gástrica quando a secreção das células parietais está sendo estimulada por mecanismos neuro-hormonais. O peptídeo da terminação $\mathrm{NH}_{2}$ permanece ligado à tripsina e age como um inativador da pepsina a valores de $\mathrm{pH}$ acima de 2. Esta inibição é liberada quando o $\mathrm{pH}$ cai a valores abaixo de 2 . O mecanismo catalítico da pepsina, a pH ácido, depende de dois grupos carboxílicos no sítio ativo da enzima. Assim, em condições favoráveis de $\mathrm{pH}$, o pepsinogênio é convertido a pepsina por autoativação e por autocatálise numa progressão exponencial. $\mathrm{O} \mathrm{HCl}$, além da função bactericida, de ativação do pepsinogênio, é 
estimulador das células principais, e desnatura proteínas globulares o que facilita a ação hidrolítica da pepsina.

$\mathrm{O}$ pH ótimo de ação da pepsina é entre 2 e 3 , sendo inativada a valores de $\mathrm{pH}$ acima de 5. Assim, acloridria, como ocorre na anemia megaloblástica ou perniciosa em que o $\mathrm{pH}$ intragástrico é $>7 \mathrm{e}$, em pacientes gastrectomizados, há aumento da excreção fecal de nitrogênio.

A pepsina é uma endopeptidase e hidrolisa proteínas nas ligações peptídicas formadas por aminogrupos de ácidos aromáticos como a fenilalanina, tirosina e triptofano, originando oligopeptídeos e não aminoácidos livres. Ela é capaz de digerir o colágeno, que é pouco hidrolisado por outras enzimas proteolíticas. A digestão do colágeno pela pepsina facilita a penetração de outras enzimas proteolíticas nos tecidos a serem digeridos. Assim, disfunção péptica causa má digestão.

Cerca de 10 a $15 \%$ das proteínas ingeridas são hidrolisadas pela pepsina resultando oligopeptídeos. A ação proteolítica da pepsina não é, porém, essencial, mas a sua importância reside na ação dos olipeptídeos hidrolisados que estimulam tanto a secreção de gastrina pelo estômago como a de colecistocinina (CCK) por células endócrinas do duodeno, estimulando as células acinares do pâncreas a secretarem enzimas.

A fase intestinal da digestão proteica luminal é efetuada pelas enzimas proteolíticas lançadas no duodeno pela secreção pancreática. A chegada do quimo ácido do estômago estimula as células endócrinas do delgado, mais concentradas no duodeno, a secretarem a secretina (células S) e a CCK (células I). Estes dois hormônios gastrintestinais estimulam, respectivamente, as células dos ductos pancreáticos a secretarem $\mathrm{NaHCO} 3$ e as células dos ácinos a secretarem enzimas. O bicarbonato não só tampona o $\mathrm{HCl}$ como gera o ambiente alcalino propício à ação das enzimas pancreáticas cujas atividades são máximas a valores de $\mathrm{pH}$ próximos à neutralidade (Quadro 22.2.).

\section{Quadro 22.2 - Fase intestinal da digestão proteica}

\section{Tripsinigênio \\ Endopeptidase \\ Tripsina}

Proenzimas: tripsinogênio, quimiotripsinogênio, pró-elastase, pró-carboxipeptidase:

Enzimas ativas: tripsina, quimiotripsina, elastase, carboxipeptidases;

Produtos finais: oligopeptídeos, di e tripeptídeos, aminoácidos livres.

São cinco as enzimas proteolíticas pancreáticas, conforme mostra o Quadro 22.2. Elas são secretadas nas formas inativas de pró-enzimas. $O$ tripsinogênio é ativado no jejuno por uma enzima da borda em escova, uma endopeptidase (enteroquinase) por clivagem de um hexapeptídeo de sua molécula originando a 
tripsina que, além de ter ação autocatalítica sobre o tripsinogênio, ativa todas as outras proteases pancreáticas, o quimiotripsinogênio, as pró-carboxipeptidases $\mathrm{A}$ e $\mathrm{B}$ e a pró-elastase, originando, respectivamente, a quimiotripsina, as carboxipeptidades A e B e a elastase.

O suco pancreático contém normalmente uma pequena quantidade de um polipeptídeo de baixo peso molecular, denominado inibidor da tripsina, que neutraliza a tripsina prevenindo sua ativação no interior dos ductos e tecido pancreático.

As enzimas proteolíticas pancreáticas têm altas especificidades. Assim, a tripsina, a quimiotripsina e a elastase são endopeptidases, hidrolisando ligações no interior das cadeias polipeptídicas. A tripsina hidrolisa ligações peptídicas cujo grupo carbonila é fornecido pela lisina e arginina. A quimiotripsina hidrolisa ligações peptídicas envolvendo resíduos de fenilalanina, tirosina e triptofano e, em menor velocidade, metionina. As carboxipeptidases são exopeptidases, removem sucessivamente aminoácidos das terminações $\mathrm{COOH}$. A elastase hidrolisa ligações peptídicas da elastina, proteína fibrosa do tecido conjuntivo.

Outras enzimas pancreáticas são as desoxiribonucleases e as ribonucleases hidrolisam, respectivamente, os ácidos desoxiribonucleicos e ribonucleicos liberando os seus nucleotídeos constituintes. Resultam da ação das proteases pancreáticas cerca de $70 \%$ de oligopeptídeos com três a oito resíduos de aminoácidos e $30 \%$ de aminoácidos livres.

As peptidases da borda em escova e citosólicas continuam a hidrólise proteica.

A hidrólise dos oligopeptídeos é continuada pelas peptidases da borda em escova e do citosol dos enterócitos. As peptidases da borda em escova são: as aminooligopeptidases, que hidrolisam peptídeos com três a oito resíduos de aminoácidos, as aminopeptidases que hidrolisam di e tripeptídeos e as dipeptil-aminopeptidases que hidrolisam di e tripeptídeos com resíduos de prolina e alanina. As peptidases citosólicas hidrolisam primariamente di e tripeptídeos, uma vez que, ao contrário do que ocorre com os carboidratos, dímeros e trímeros derivados da hidrólise proteica são absorvidos através da ML dos enterócitos do delgado, sendo hidrolisados no citosol originado aminoácidos absorvidos através da MBL. 


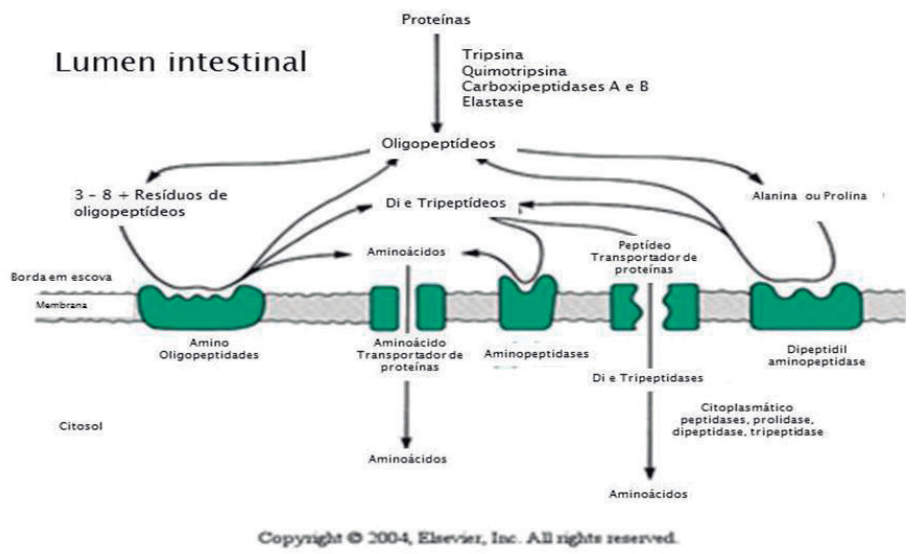

Figura 22.1 1 - Digestão luminal e na borda em escova das proteínas. (de Van Dyke RW em: Mechanisms of digestion and absorption of food. Em: Scleisenger MH \& Fordtran JS, editors: Gastrintestinal disease, 4. ed., Phyladelphia, 1989, WB Saunders (retirado do Berne RM et al. Em: Physiology, 5. ed. Mosby Inc, 2004).

Há, assim, um grande número de peptidases responsáveis pela digestão proteica, uma vez que os oligopeptídeos contêm 24 diferentes aminoácidos. Estas peptidases são altamente específicas reconhecendo apenas determinados repertórios de ligações peptídicas. Há, entretanto, um número menor de peptidases citosólicas do que as da borda em escova.

Os processos digestivos das proteínas e os de absorção dos seus produtos de hidrólise completam-se até o íleo proximal.

O influxo de aminoácidos através da ML dos enterócitos ocorre por vários sistemas transportadores.

$\mathrm{Da}$ ação das proteases luminais e peptidases da borda em escova resultam tri e dipeptídeos e aminoácidos livres que são absorvidos através da ML ou borda em escova dos enterócitos. No intracelular, por ação das peptidases citosólicas, os tri e dipeptídeos são hidrolisados a aminoácidos. Através da MBL só são absorvidos aminoácidos livres, conforme ilustra o esquema da Figura 22.11.

\section{Absorção de aminoácidos livres, di, tri, e tetrapeptídeos.}

Embora múltiplos sistemas de transporte de aminoácidos em células não epiteliais sejam descritos, na ML dos enterócitos há pelo menos 7 sistemas transportadores reconhecidos, com afinidades pouco específicas aos diversos aminoácidos, conforme resumido abaixo no Quadro 22.3 e na Figura 22.12. 
Destes transportadores, o sistema B é o predominante. Cerca de $10 \%$ dos aminoácidos no intracelular dos enterócitos, tanto os transportados como aminoácidos livres como os hidrolisados pelas peptidases citosólicas, a partir dos di e tripeptídeos, são utilizados pelos enterócitos para a síntese proteica.

Transporte de aminoácidos através da membrana basolateral (MBL) pode ocorrer no sentido absortivo como no sentido do compartimento vascular para o enterócito.

Há cinco processos descritos para o transporte de aminoácidos através da MBL. Dois destes processos transportam aminoácidos do compartimento vascular para o intracelular dos enterócitos. Estes aminoácidos funcionam como fonte energética para estas células. Os três processos restantes ocorrem no sentido absortivo conforme está resumido nos Quadros 22.3 e 22.4.

\section{Quadro 22.3 - Influxo de aminoácidos mediado por carregadores através da ML dos enterócitos}

1. Sistema Y+: difusão facilitada de aminoácidos básicos ou catiônicos sem acoplamento com o Na+. Exemplos: arginina, lisina histidina e ornitina

2. Sistema b b.t: $^{0}$ difusão facilitada de aminoácidos neutros, básicos e de cisteína, sem acoplamento com o Na+

3. Sistema B: transporte ativo secundário eletrogênico de aminoácidos neutros por cotransporte com o $\mathrm{Na}^{+}$.

4. Sistema $B^{0,+}$ : transporte ativo secundário de aminoácidos neutros, básicos e de cisteína por cotransporte com o $\mathrm{Na}^{+}$.

5. Sistema IMINO: transporte ativo secundário de iminoácidos (prolina e hidroxiprolina) por cotransporte com $\mathrm{Na}^{+} \mathrm{e} \mathrm{Cl}$

6. Sistema: $\beta$ : transporte ativo secundário de $\beta$-aminoácidos, betaína, ácido gama amino butírico (GABA) e taurina por cotransporte com $\mathrm{Na}^{+} \mathrm{e}$ Cl.

7. Sistema X: ${ }^{-16}$ : transporte ativo secundário de aminoácidos ácidos ou aniônicos em acoplamento com o $\mathrm{Na}^{+}$(sentido absortivo) e $0 \mathrm{~K}^{+}$(sentido secretor) como glutamina e aspartato.

\section{Quadro 22.4 - Transporte de aminoácidos através da MBL dos enterócitos}

1. Sistema A: influxo para os enterócito por cotransporte de $\mathrm{Na}^{+}$e de aminoácidos. Aminoácidos neutros, iminoácidos e glutamina.

2. Sistema ASC: influxo para o enterócito por cotransporte de $\mathrm{Na}^{+}$e de aminoácidos. Aminoácidos neutros, Alanina, Serina e Cisteína.

3. Sistema asc: difusão facilitada de alanina, serina e cisteína no sentido enterócito-plasma.

4. Sistema L: difusão facilitada de cisteína, glutamina, aminoácidos neutros e hidrofóbicos no sentido enterócito- plasma.

5. Sistema Y+: difusão facilitada de aminoácidos básicos, lisina, arginina, ornitina e dina no sentido enterócito- plasma. 


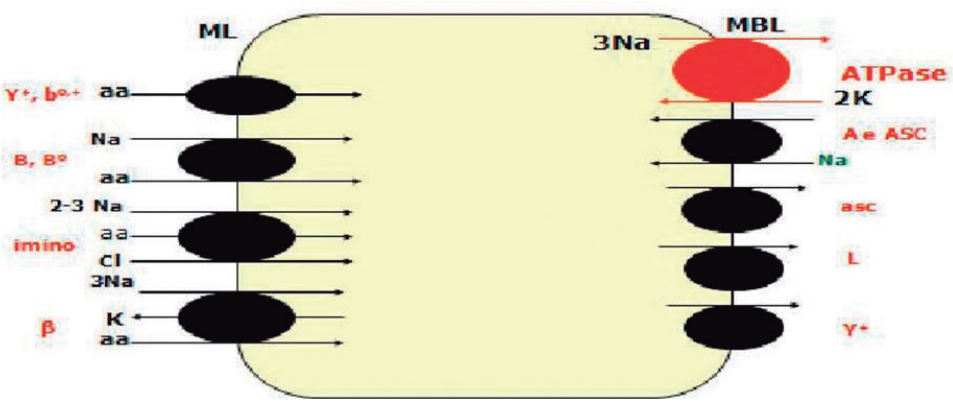

Figura 22.12 - Sistemas de transporte de aminoácidos livres através da membrana luminal (ML) dos enterócitos. (de Berne RM et al. Em: Physiology, 5. ed. Mosby Inc, 2004). Estes sistemas foram descritos nos Quadros 22.3 e 22.4.

A absorção de di, tri e tetrapeptídeos ocorre através de um contransportador dependente do gradiente de potencial eletroquímico de $\mathrm{H}^{+}$através da $\mathrm{ML}$.

Um contratransportador eletrogênico $2 \mathrm{H}^{+}$:oligopeptídeo da $\mathrm{ML}$, denominado Pep- $T_{1}$ presente, também, no túbulo proximal do néfron, é o responsável pelo influxo de peptídeos para o enterócito. Este transportador utiliza o gradiente de $\mathrm{pH}$ gerado pelo contratransporte $\mathrm{Na}^{+} / \mathrm{H}^{+}$que move $\mathrm{H}^{+}$para o intracelular por transporte ativo secundário em acoplamento com o influxo de $\mathrm{Na}^{+}$. Os peptídeos são hidrolisados no interior dos enterócitos por peptidases citosólicas a aminoácidos livres que são transportados através da MBL por um dos mecanismos acima expostos no Quadro 22.4 e na Figura 22.13.

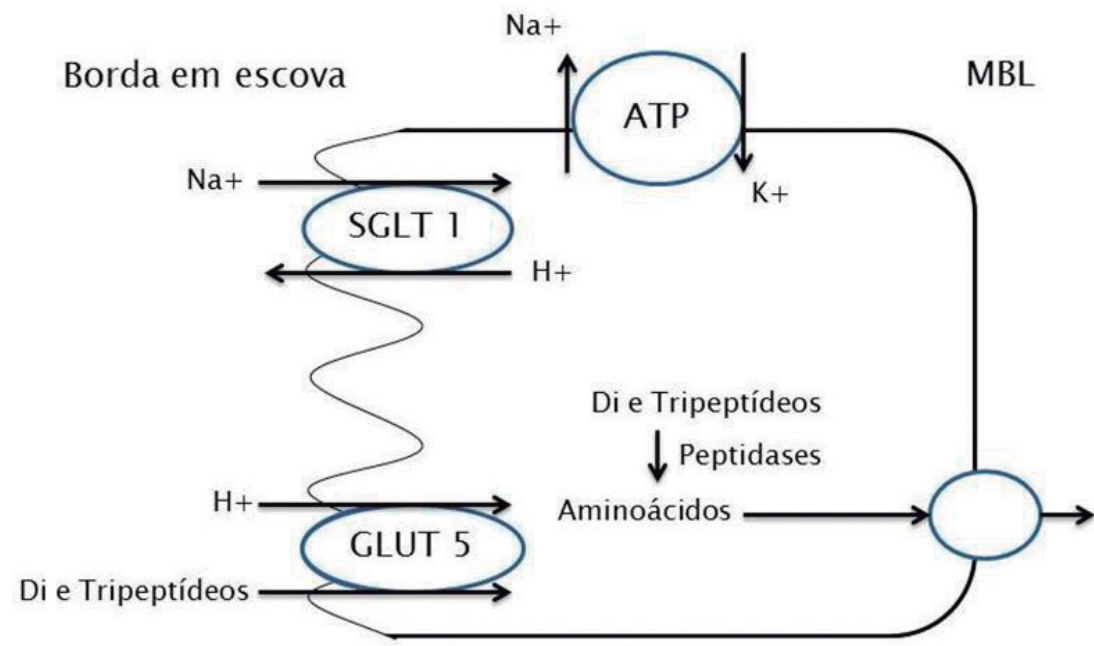

Figura 22.13 - A absorção de di, tri e tetrapeptídeos ocorre através de um contransportador dependente do gradiente de potencial eletroquímico de $\mathrm{H}+$ através da ML (Brush border. Borda em escova); MBL (membrana basolateral). 
A absorção de di, tri e tetrapeptídeos ocorre de maneira mais rápida do que a de aminoácidos livres e este processo é referido como "vantagem cinética", sendo utilizados na alimentação enteral, uma vez que estes, além de serem mais rapidamente absorvidos, causam menor efeito osmótico do que os aminoácidos livres.

O aparecimento de aminoácido administrado na forma de peptídeo (glicilglicina) na circulação porta ocorre mais rapidamente do que o aparecimento do mesmo aminoácido livre (glicina) como ilustra o experimento esquematizado na Figura 23.14.

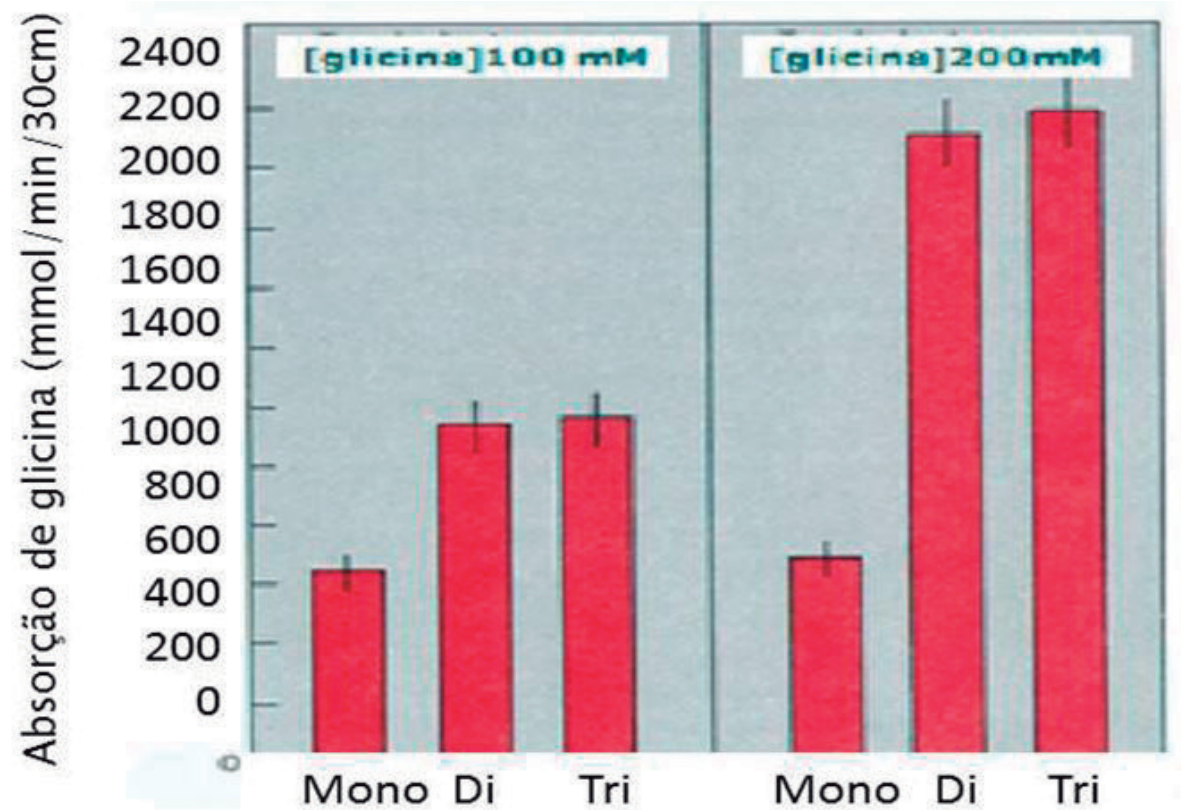

Figura 22.14 - Absorção de aminoácido livre, glicina, nas formas de mono-,di- e tripeptídeo.

\section{A absorção de peptídeos tem importância nutricional e clínica.}

Tem sido demonstrado em animais e em humanos que misturas de peptídeos são nutricionalmente superiores às misturas contendo aminoácidos livres. As razões para isto já foram parcialmente mencionadas. São elas: (a) a absorção de aminoácidos na forma de peptídeos ocorre mais rapidamente do que na forma de aminoácidos livres; (b) a absorção de di, tri ou tetrapeptídeos evita problemas de competição com os transportadores da ML dos enterócitos, o que pode ocorrer com os aminoácidos livres; (c) a absorção de formas oligoméricas é energeticamente mais vantajosa para as células do que a de formas monoméricas; (d) os peptídeos são mais resistentes do que os aminoácidos ao jejum, às carências proteico-calóricas, às carências vitamínicas e às doenças intestinais. 
As vantagens clínicas referem-se à alimentação enteral. Soluções de peptídeos comerciais contêm aminoácidos essenciais e não essenciais. Soluções de peptídeos são mais osmoticamente hipoosmolares do que as de aminoácidos livres prevenindo quadros diarreicos em pacientes com alimentação enteral. Muitos aminoácidos livres são pouco hidrossolúveis, como a tirosina, ou instáveis em solução, como a glutamina e a cisteína. Em geral em algumas patologias do TGI o comprometimento da absorção de aminoácidos é maior do que a de peptídeos.

A absorção de aminoácidos e peptídeos é regulada por fatores intrínsecos e extrínsecos.

A capacidade intestinal para absorver aminoácidos e peptídeos varia significantemente em várias condições como: períodos de desenvolvimento ontogenético do indivíduo, lactação, gestação e em resposta a doenças.

As taxas de absorção de aminoácidos e peptídeos variam com a idade do organismo tanto em animais como em humanos. Os sistemas transportadores estão presentes no intestino fetal, embora não se tenha conseguido precisar o tempo exato de aparecimento de cada um deles em particular. No recém-nascido todos os sistemas transportadores estão presentes no intestino, ocorrendo uma diminuição com a idade da capacidade absortiva para aminoácidos e peptídeos, alcançando no adulto, cerca de níveis 2,5 a 5 vezes inferiores comparativamente aos do recém-nascido. A diminuição é comparativamente maior para a capacidade absortiva dos aminoácidos essenciais do que para os não essenciais.

Com relação à regulação pela qualidade da dieta, a taxa de transporte de todos os nutrientes orgânicos é regulada pelos seus níveis na luz intestinal, embora os mecanismos responsáveis por esta regulação sejam pouco esclarecidos.

Vários hormônios, parácrinos e neurotransmissores regulam os processos absortivos de nutrientes orgânicos em geral. No caso dos aminoácidos, a somatostatina diminui a absorção de lisina, glicina e leucina. O peptídeo vasoativo intestinal (VIP) diminui o transporte de leucina, a neurotensina, a colecistocinina (CCK) e a secretina o aumentam. $O$ fator de crescimento epidérmico aumenta o transporte de alanina e glutamina.

\section{A absorção de proteinas intactas ocorre durante o periodo neonatal e na idade adulta.}

Em recém-nascidos, ocorre absorção de imunoglobulinas do colostro por endocitose através da ML dos enterócitos e de outras imunoglobulinas como um mecanismo de defesa imunológica de mãe para filho que perdura até os seis meses de vida, cessando em seguida por regulação hormonal.

Em adultos acontece eventualmente absorção intestinal de proteínas imunologicamente importantes e de polipeptídeos, mas os mecanismos envolvidos 
neste processo são pouco elucidados e provavelmente diferem dos processos que sucedem nos recém-nascidos. Há indicações de que os enterócitos podem efetuar endocitose de proteínas que são posteriormente degradas nos lisosomas.

Um via absortiva mais específica ocorre através das células $M$ dos folículos das placas de Peyer onde as proteínas são armazenadas em vesículas envoltas por clatrina que são secretadas através da MBL para a lâmina própria onde células imuno-competentes transferem a proteína a linfócitos que iniciam a resposta imune.

Doença de Hartnup ou aminoacidúria: é uma doença genética recessiva cujo nome é da família onde foi primeiramente descrita. Consiste em defeito na absorção intestinal e renal de aminoácidos neutros, especificamente do sistema B de transporte da ML tanto dos enterócitos como dos túbulos proximais do néfron. 0 defeito clínico é um aumento da excreção renal de aminoácidos neutros essenciais como o triptofano, precursor da síntese de nicotinamida. Neste caso podem aparecer sintomas semelhantes à pelagra que acompanham a doença. Quando os sistemas de absorção intestinal de peptídeos não estão alterados nestes individuos, os aminoúcidos neutros podem ser absorvidos e não há carência nutricional. Cistinúria: é um defeito genético dos sistemas $\mathbf{B}^{\mathrm{B},+} \mathrm{e} \mathbf{b}^{0,+}$, da ML tanto do enterócito como do túbulo proximal do néfron, comprometendo a absorção de aminoácidos neutros e básicos, lisina, arginina e cisteína que são excretados na urina. Também esta doença não causa problemas nutricionais. A principal manifestação desta doença é a formação de cálculos renais. Intolerância lisinúrica proteica: defeito genético no sistema IMINO da ML dos enterócitos e dos túbulos proximais do néfron, para prolina e hidroxiprolina que são excretadas na urina. Não há carência nutricional. Intolerância proteica lisinúrica defeito genético do sistema $\mathbf{Y}^{+}$de transporte de aminoácidos catiônicos da MBL dos enterócitos. Neste caso, há problemas nutricionais. Esta defeito está presente também em hepatócitos e células renais e, provavelmente em células não epiteliais.

\section{RESUMO}

1. Há cerca de 35 a 200 g de proteínas endógenas na luz do delgado que resultam da descamação das células, do muco e das secreções do SGI. Elas são completamente digeridas e absorvidas, como as proteínas da dieta. Proteínas encontradas nas fezes originam-se do cólon.

2. A pepsina hidrolisa cerca de 10 a $15 \%$ das proteínas da ingesta. O pepsinogênio é ativado na luz gástrica pelo $\mathrm{HCl}$ que também cria o $\mathrm{pH}$ adequado para a sua ação catalítica.

3. No delgado, a digestão proteica luminal é efetuada pela tripsina, quimiotripsina e elastase, que são endopeptidases e pelas carboxipeptidases, exopeptidases. A hidrólise dos oligopeptídeos é continuada pelas enzimas da borda em escova, as aminooligopeptidases, aminopeptidases e dipeptil-peptidases.

4. Tetra, tri, e dipeptídeos podem ser absorvidos através da ML dos enterócitos. São hidrolisados pelas peptidases citosólicas e absorvidos na MBL por sistemas específicos de transporte. Os peptídeos são absorvidos mais rapidamente do que os aminoácidos livres.

5. Os aminoácidos livres são transportados através da ML dos enterócitos por sistemas específicos de transporte em acoplamento com o $\mathrm{Na}^{+}$ou com outros 
íons. A carga resultante dos aminoácidos determina o mecanismo de transporte na ML e na MBL.

6. Os sistemas de acoplamento de aminoácidos com o $\mathrm{Na}^{+}$existentes na $\mathrm{MBL}$ transportam os aminoácidos do interstício para o citosol dos enterócitos, como os neutros, alanina, serina e cisteína, os iminoácidos e a glutamina. Estes aminoácidos são fonte energética para o metabolismo dos enterócitos.

7. Absorção de proteínas intactas ocorre por endocitose em recém-nascidos, principalmente de imunoglobulinas do colostro. Em adultos pode ocorrer endocitose de protéinas imunologicamente ativas pelas células $\mathrm{M}$ dos domos foliculares.

\subsection{DIGESTÃO E ABSORC̣ÃO DE LIPÍDEOS}

Os principais lipídeos da dieta são as gorduras neutras, o colesterol e os fosfolipídeos.

Lipídeos são moléculas de complexidade estrutural variável, predominantemente de natureza hidrocarbônica, o que lhes confere a propriedade de serem solúveis em solventes orgânicos. Um indicador largamente utilizado da natureza lipídica de um composto é seu coeficiente de partição octanol/água que, para a maioria dos lipídeos, é entre $10^{4}$ e $10^{7}$.

Embora a dieta possa conter vários tipos de lipídeos complexos de origem animal e vegetal, trataremos aqui apenas dos lipídeos quantitativamente mais importantes na dieta típica do mundo ocidental. Estes são: os triacilgliceróis (TAG) ou gorduras neutras, o colesterol (Col), os ésteres de colesterol (Col-E) e os fosfolipídeos (FL). As estruturas destas moléculas estão mostradas na Figura 22.15. 


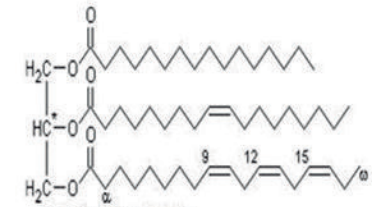

Triglicéride

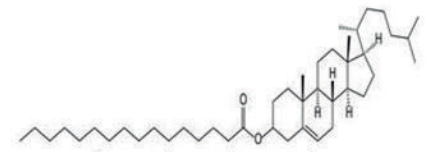

Éster de colesterol
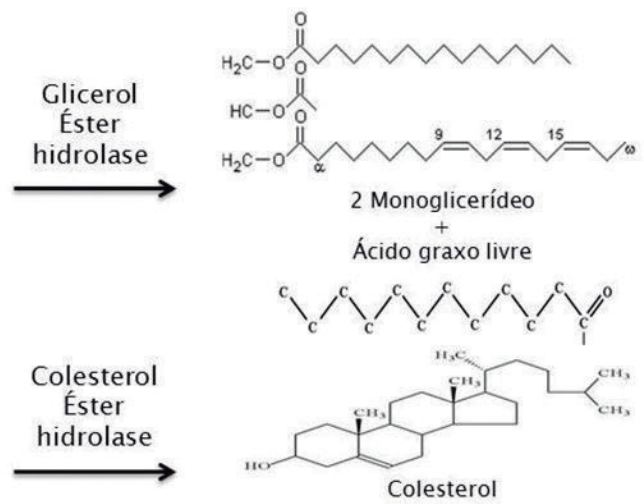

Ácido graxo livre
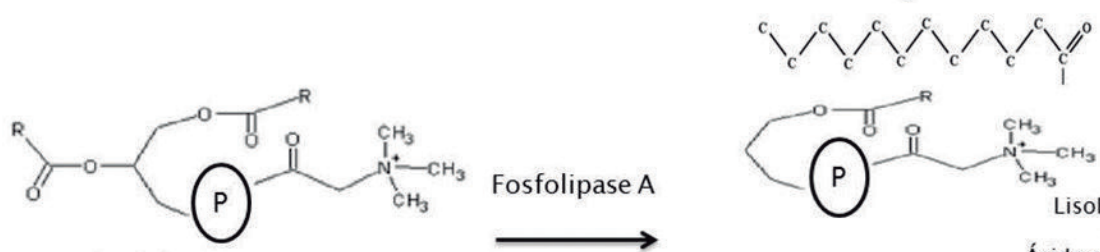

Lecitina
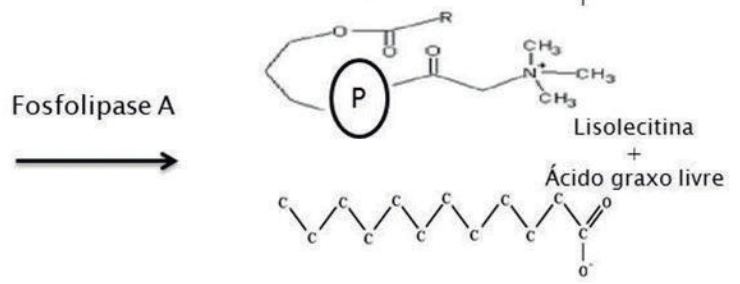

Figura 22.15 - 0s três principais lipídeos da dieta e os processos hidroliticos pelas enzimas pancreáticas com os produtos finais da hidrólise. (adaptado de Berne et al., (2014)

Os TAG resultam de processos de esterificação das três hidroxilas do glicerol por ácidos graxos de cadeias longas. Estes últimos são frequentemente: o ácido oléico, com 18 átomos de carbono e uma dupla ligação cis entre os carbonos 9 e 10 (18:1); o palmítico, com 16 átomos de carbono saturados (16:0) e o esteárico com 18 átomos de carbono (18:0). Os TAG são a principal fonte energética do organismo, pois além de fornecerem $9 \mathrm{kcal} / \mathrm{g}$, acumulam-se no intracelular na forma concentrada e anidra. O colesterol contém uma hidroxila na posição 3 do anel esteroídico que é esterificado por ácidos graxos de dimensões variáveis. Nos fosfolipídeos, um dos grupos hidroxila do glicerol é esterificado pelo ácido fosfórico e os outros dois por ácidos graxos de cadeias longas. Os FL mais abundantes são a fosfatidiletalonamina (ou cefalina) e a fosfatidilcolina (ou lecitina). Os dois são os principais fosfolipídeos das membranas celulares.

Numa dieta balanceada, os lipídeos devem fornecer de 30 a $40 \%$ das calorias; entretanto, na dieta do mundo ocidental, eles chegam a perfazer $50 \%$ das calorias totais, o que significa uma ingestão entre 140 e $160 \mathrm{~g} /$ dia nas formas de 1/3 de lipídeos originários da carne, $1 / 3$ da manteiga e óleos e 1/5 de leite e derivados. Esta quantidade de gordura corresponde a uma concentração plasmática de 500 mg\%. 
Destes, $44 \%$ são representados pelo colesterol, $32 \%$ por fosfolipídeos e $24 \%$ por TAG. A quantidade de gordura na dieta tem sido preocupação de nutricionistas e médicos nas últimas décadas devido à elevada correlação entre o nível de gorduras, principalmente as que contêm ácidos graxos saturados (com exceção do ácido esteárico), e o nível de colesterol plasmático com o risco de doenças cardiovasculares e aterosclerose. Recomenda-se que as gorduras devam fornecer apenas 30\% ou menos das calorias diárias e a média de ácidos graxos saturados deve ser inferior a $10 \%$.

Os TAG da dieta contribuem com cerca de $80 \%$ do total de calorias. Entre os fosfolipídeos, a fosfatidilcolina é quantitativamente o mais significativo, sendo que a grande parte é originária da bile. O esterol mais abundante da dieta é o colesterol, predominantemente de origem animal. $\mathrm{O}$ de origem vegetal é encontrado em batatas e na aveia. Os esteróis vegetais perfazem cerca de 20 a $25 \%$ da dieta como o $\beta$-sitosterol.

Os lipídeos endógenos no TGI são os provenientes da bile: $10-15 \mathrm{~g} / \mathrm{dia}$ de fosfolipídio, predominantemente a lecitina e o colesterol não esterificado 1 a 2 g/ dia. Quantitativamente os lipídeos biliares excedem cerca de dois a quatro vezes os provenientes da dieta. Há, também, os lipídeos provenientes das células descamadas do TGI perfazendo um total de 2 a 6 g/dia e cerca de $10 \mathrm{~g} /$ dia de lipídeos das bactérias mortas que são adicionados ao cólon.

As gorduras animais são sólidas na temperatura ambiente, contendo lipídeos nos quais a maioria dos ácidos graxos é saturado (palmítico e esteárico), enquanto as gorduras vegetais são líquidas, a maioria com ácidos graxos insaturados (oleico e linoleico).

\section{A emulsificação mecânica das gorduras da dieta na cavidade oral e no estômago.}

Como os lipídeos são pouco solúveis no fluido luminal do TGI, eles formam gotas em suspensão e, como as enzimas lipolíticas são hidrossolúveis, elas agem apenas na interface lipídeo/água. A quebra das gotas de gordura em gotas cada vez menores eleva a relação área superficial/volume, amplificando a área de interface para a ação das enzimas e otimizando o processo hidrolítico. Esta quebra das gotas de gordura em gotículas denomina-se emulsificação que se inicia com os processos de preparo do alimento e prossegue pela mastigação na cavidade oral, pela motilidade gástrica, principalmente pelos movimentos de mistura e trituração nas sístoles antrais e pelos movimentos de mistura do delgado. Assim, as gorduras são misturadas às secreções salivar, gástrica, pancreática e biliar. A emulsificação ou quebra das gotas de gordura em gotículas pelos movimentos do TGI também impede a coalescência das gotículas favorecendo a sua estabilização, uma vez que elas ficam recobertas por lipídeos, proteínas desnaturadas, polissacarídeos parcialmente digeridos e pelos produtos da digestão das próprias gorduras (ácidos graxos, e monacilgliceróis) como também pelos fosfolipídeos e colesteróis 
biliares. Os fosfolipídeos e colesterol são bons estabilizadores das gotículas porque, sendo anfifílicos, expõem suas cabeças polares à agua e suas regiões hidrofóbicas às gorduras, formando monocamadas e mantendo no interior das gotículas os TAG, os ésteres de colesterol e outros lipídeos não polares.

\section{As lipases pré-duodenais, a lingual e a gástrica iniciam a digestão dos lipídeos.}

A lipase lingual, secretada pelas glândulas de von Ebner da língua inicia a digestão lipídica na boca. No estômago, a lipase lingual deglutida e a lipase gástrica continuam o processo hidrolítico. Estas duas lipases são, também, denominadas lipases ácidas, porque são ativas a valores de $\mathrm{pH}>4$. Há grandes diferenças entre as duas lipases nas espécies animais: assim, em ratos e camundongos, predomina a lipase lingual; em cobaias, macacos e humanos, predomina a gástrica. A lipase lingual tem seu pH ótimo de ação entre 6 a 6,5 e continua ativa no duodeno, a gástrica (em humanos) tem o pH ótimo de ação entre 3 e 6 . A lipase lingual de rato foi a primeira a ser clonada. É uma proteína com PM de $52 \mathrm{kDa}$ com 337 aminoácidos. A lipase gástrica tem o PM de $42 \mathrm{kDa}$ e apresenta cerca de $78 \%$ de homologia na seqüência aminoacídica com a lipase lingual de rato e, como ela, tem pouco homologia com a lipase pancreática. A lipase gástrica é uma glicoproteína secretada pelas células principais gástricas e sua secreção é estimulada pela gastrina. É resistente à ação da pepsina e não é inibida pela camada lipídica superficial que recobre as gotículas de gordura já emulsificadas. Entretanto, as lipases pré-duodenais em humanos são inativadas pelo $\mathrm{pH}$ alcalino do duodeno devido às secreções pancreática e biliar.

Em recém-nascidos, a secreção de lipase gástrica é bem estabelecida, ao contrário da lipase pancreática, e a sua ação hidrolítica sobre a gordura do leite é importante no período neonatal. Em adultos, normalmente a quantidade de lipase pancreática é grande e a ausência da lipase gástrica não provoca problemas de má-absorção lipídica; entretanto, quando a quantidade de lipase pancreática é diminuída, por insuficiência pancreática ou fibrose cística, ou quando ela é inativada no duodeno por uma hipersecreção de $\mathrm{HCl}$ gástrico, como ocorre, por exemplo, na síndrome de Zollinger-Ellison (gastrinoma), a hidrólise das gorduras pelas lipases pré-duodenais passa a ser essencial e elas podem continuar a agir no ambiente pouco alcalino do duodeno que ocorre nesta condição. Assim, estas ações das lipases pré-duodenais aliviam parcialmente os problemas de má-absorção lipídica por insuficiência pancreática.

As lipases pré-duodenais hidrolisam os TAG, liberando um ácido graxo de cadeia longa e produzindo diacilgliceróis. Os grupos carboxílicos destes ácidos graxos, no ambiente acídico do estômago, são protonados e insolúveis e permanecem no interior das gotículas de gordura. Como as lipases hidrolisam os TAG com cadeias médias e curtas de ácidos graxos, estas espécies químicas protonadas são menos lipossolúveis e podem atravessar a mucosa gástrica entrando diretamente 
na circulação porta. Em adultos humanos saudáveis, aproximadamente $15 \%$ da digestão lipídica ocorre no estômago.

\section{e biliar. \\ A importância da hidrólise lipídica pré-duodenal sobre a secreção pancreática}

O esvaziamento do quimo gástrico no duodeno estimula tanto a secreção aquosa alcalina dos ductos pancreáticos como a secreção enzimática das células acinares por mecanismos neuro-hormonais. $\mathrm{O}$ pH ácido do quimo no duodeno estimula as células $S$ a secretarem secretina que, caindo na circulação sistêmica, estimula a secreção aquosa dos ductos extralobulares do pâncreas, contendo cerca de $140 \mathrm{mM}$ de $\mathrm{NaHCO}_{3}$. Esta secreção é lançada pelo ducto biliar comum no duodeno, logo abaixo do piloro e, além de tamponar o $\mathrm{HCl}$, cria ambiente alcalino adequado para a atividade das enzimas pancreáticas.

Os produtos da hidrólise lipídica, provenientes da digestão das gorduras pelas lipases pré-duodenais, são o principal estímulo para a liberação pelas células I da CCK (colecistocina) que estimula a secreção das enzimas pancreáticas lançadas no duodeno. A CCK também tem efeito colagogo, contraindo a musculatura lisa da vesícula biliar e relaxando o esfíncter de Oddi, o que propicia a secreção da bile para o duodeno. A bile é de extrema importância na digestão e na absorção das gorduras como será analisado mais para frente. Os produtos da hidrólise lípídica estimulam também a secreção de GIP (peptídeo inibidor gástrico) que retarda a velocidade de esvaziamento gástrico por contração pilórica. Estas ações motoras são, também, efetuadas pela secretina e pela CCK, o que permite ao delgado processar adequadamente o quimo.

A hidrólise lipídica continua no duodeno e jejuno pelas enzimas lipolíticas pancreáticas.

As enzimas lipolíticas pancreáticas são: a glicerol-éster-hidrolase (lipase pancreática), a colesterol-éster-hidrolase e as fosfolipases $\mathbf{A}_{2}$. Apenas as fosfolipases são lançadas na luz do delgado na forma de pró-enzima inativa, sendo ativada pela tripsina. É secretada, também, pelo pâncreas, uma pró-colipase, ativada na luz do delgado também pela tripsina. A colipase não tem atividade hidrolítica, mas age como cofator para a ação da lipase, por este motivo, a lipase é, também, denominada lipase pancreática dependente da colipase.

A lipase pancreática em adultos, mas não nas crianças, é secretada em quantidades cerca de mil vezes superior à sua necessidade, constituindo 2 a $3 \%$ do conteúdo proteico total da secreção pancreática. Esta elevada quantidade, aliada a sua alta atividade hidrolítica, assegura a eficiência da digestão lipídica. Realmente, para que se instale uma esteatorreia (excreção de gorduras nas fezes acima de $7 \mathrm{~g} / 150 \mathrm{~g}$ de fezes) é necessário que a lipase pancreática seja reduzida a valores 
cerca de $90 \%$ inferiores aos normais. Esta enzima já foi sequenciada em suínos e é uma glicoproteína com PM de 48 kDa com 449 aminoácidos com um resíduo serina na posição 152 que parece ser o sítio ativo de ligação da enzima para a sua ancoragem às gotículas de gordura.

Para a total atividade da lipase pancreática, é necessária a colipase. A colipase foi descrita em 1963 como uma proteína termoestável necessária para a ação da lipase. A colipase tem o PM de $10 \mathrm{kDa}$, é secretada na luz do delgado na forma de pró-colipase. Ela é clivada pela tripsina no terminal $\mathrm{N}$ de um pentapeptídeo, conhecido como enterostatina. A colipase de várias espécies animais, inclusive da humana, já foi clonada e o seu gene localiza-se no cromossoma 6. O sítio de ligação da colipase à lipase localiza-se em duas regiões, os aminoácidos 6-9 e 53-59.

Estudos com a lipase pancreática demonstram, que quando a enzima se encontra livre em solução, o seu sítio catalítico localiza-se numa fenda de sua molécula parcialmente recoberta por uma alça de sua cadeia peptídica. A interação da colipase com a enzima induz uma alteração conformacional da lipase movendo a alça que recobria o sítio catalítico propiciando ao substrato lipídico difundir-se ao sítio catalítico agora exposto.

Os sais biliares sob forma micelar também provocam a emulsificação das gotas de gordura já previamente emulsificadas no estômago, elevando ainda mais a área superficial das gorduras para a ação lipolítica. Os movimentos do delgado facilitam a emulsificação. Entretanto, os agentes emulsificadores inibem a lipólise recobrindo externamente as gotículas emulsificadas e, assim, impedindo a interação da lipase pancreática com as gorduras. A colipase reverte esta inibição por dois prováveis mecanismos, ligando-se à interface e servindo como uma âncora para a ligação da lipase, ou formando um complexo colipase-lipase que se liga à interface das gotículas com a água e permitindo a ação hidrolítica da lipase. As micelas dos sais biliares não só permitem a proximidade da colipase com as gotículas mas participam, também, da remoção dos produtos da hidrólise lipídica das gotículas. Os ácidos graxos aumentam também a lipólise porque provavelmente elevam a ligação do complexo colipase-lipase com as gotículas.

A lipase pancreática hidrolisa as ligações ésteres dos TAG nos carbonos 1 e 3 originando os 2-monoacilgliceróis (2-MAG) e ácido graxo livre de cadeia longa (AGL-CL). Os AGL-CL, no pH alcalino da luz do delgado, estão nas formas ionizadas (Figura 22.15).

A maioria do colesterol da dieta está sob forma livre. Apenas, 10 a $15 \%$ estão na forma esterificada. A colesterol-éster-hidrolase hidrolisa os ésteres de colesterol originando o colesterol livre e AGL-CL. A colesterol-éster-hidrolase foi clonada em várias espécies animais, inclusive em humanos, onde seu PM é de 100 
$\mathrm{kDa}$. Apresenta ampla especificidade, podendo hidrolisar, também, ligações ésteres do TAG. A atividade desta enzima é aumentada pelos sais biliares.

A fosfolipase $\mathbf{A}_{2}$, liberada do pâncreas na forma inativa de pró-enzima, é ativada pela tripsina na luz do delgado por clivagem de um heptapeptídeo na terminação $\mathrm{NH}_{2}$. Esta enzima hidrolisa as ligações ésteres do carbono 2 dos fosfolipídeos liberando um AGL-CL (ácidos graxos livres de cadeia longa) e originando os lisofosfolipídeos (Figura 22.15). A fosfolipase $\mathrm{A}_{2}$ pode também ser derivada das células de Paneth no delgado.

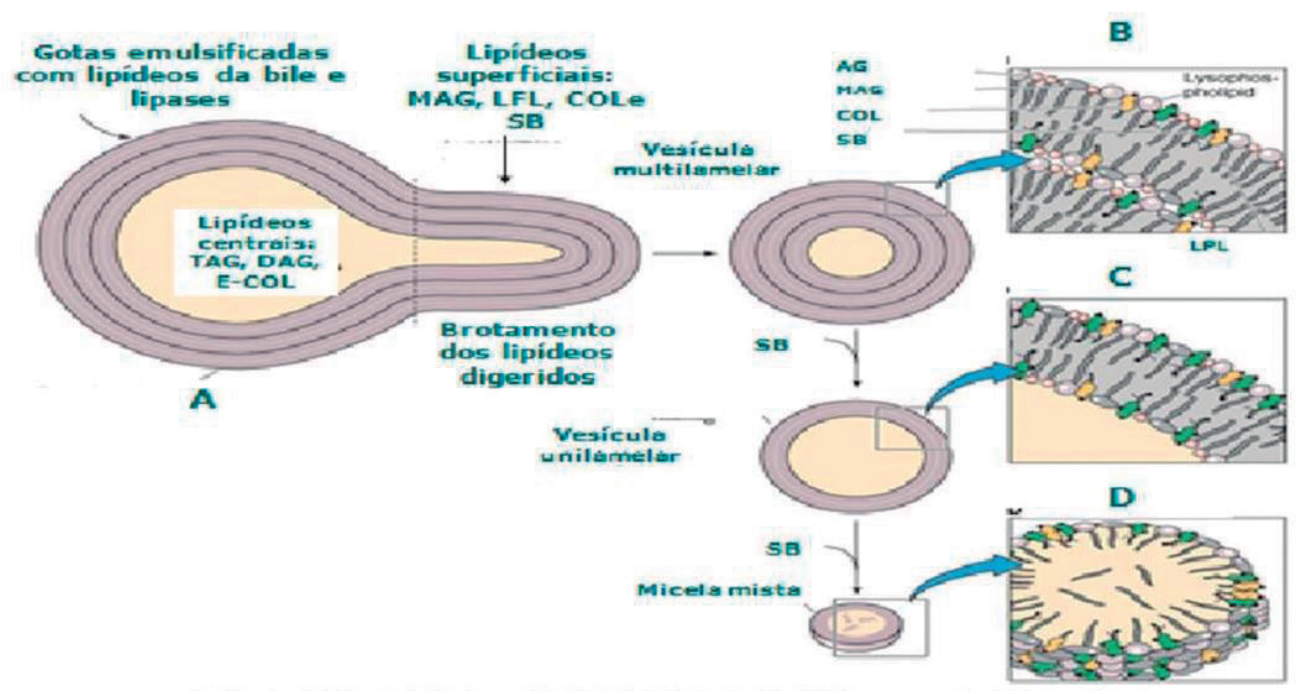

Figura 22.16-A quebra das gotículas emulsificadas (A) formando vesículas multilamelares (B), vesícula unilamelares (C) e micelas mistas (D). $\mathrm{COL}=$ colestrol livre; $\mathrm{E}-\mathrm{COL}=$ colesterol esterificado; $\mathrm{DAG}=$ diacilglicerol; $\mathrm{LPL}=$ lisofosfolipídeo ou lisolecitina; $M A G=$ monoacilglicerol; $S B=$ sal biliar; $T A G=$ triacilglicerol. Explicação no texto. (do livro de Mediacal Physiology, Boron WF e Boulpaep EL, updated ed., 2005).

A fosfolipase $A_{2}$ encontrada no cólon provavelmente resulta da fermentação bacteriana. No cólon há também outras lipases, mas diferentemente das lipases do delgado, elas não são específicas com relação aos substratos, agem em pH ácídicos, não requerem cofatores e não são inibidas pelos sais biliares. Estas lipases de origem bacteriana hidrolisam TAG e fosfolipídeos. A gordura fecal, portanto, resulta da ação destas lipases e fosfolipases e contém, também, esteróis. Mesmo em casos de má-absorção lipídica, TAG intactos nas fezes são raramente encontrados. 
Vesículas multilamelares, unilamelares e micelas mistas solubilizam os produtos da hidrólise lipídica na fase aquosa luminal do delgado.

Os componentes da bile, sais biliares, colesterol, lecitina e lipase pancreática ficam adsorvidos às superfícies das gotículas emulsificadas de gordura. Os produtos da hidrólise lipídica, os 2-MAG, os AGL-CL, as lisolecitinas e o colesterol também funcionam como agentes emulsificadores. Como os TAG superficiais das gotículas são hidrolisados, são substituídos por outros do interior das gotículas que vão, assim, tornando-se cada vez menores. Estas gotículas multilamelares emulsificadas (Figura 22.16A) contêm camadas ou lamelas líquido-cristalinas de AGL-CL, 2-MAG, lisofosfolecitinas, e sais biliares e originam, por brotamento (dependente de $\mathrm{Ca}^{2+}$ ), vesículas esféricas multilamelares de igual composição (Figura 22.16B). As micelas dos sais biliares transformam estas vesículas multilamelares em vesículas unilamelares (Figura 22.16C) que são simplesmente bicamadas lipídicas e, finalmente em micelas mistas (Figura 16D) contendo sais biliares e os produtos da hidrólise lipídica (2-MAG, MAG, AGL-CL, lisofosfolipídeos e colesterol).

As micelas mistas carregam os produtos da hidrólise lipidica através da camada não agitada de água da superfície luminal do jejuno e liberam os monômeros que penetram os enterócitos.

$\mathrm{Na}$ solução luminal, denominada "bulk solution" (Figura 22.16), as gotículas emulsificadas estão em equlíbrio com as vesículas multilamelares, unilamelares e com as micelas mistas dos quais os componentes, os produtos da hidrólise lipídica e os sais biliares se associam e se dissociam de acordo com seus coeficientes de partição nas duas fases, a aquosa e a vesicular e/ou micelar. Até alcançar a ML dos enterócitos as micelas têm que atravessar o gel mucoso que forra a superfície luminal e a camada não agitada de água. O gel mucoso, embora seja constituído por $95 \%$ de água parece ser a principal barreira para a difusão dos microagregados lipídicos, particularmente as vesículas que estão em equilíbrio com as micelas mistas e os monômeros dissociados. A espessura da camada não agitada de água tem sido calculada com base na difusão de vários "probes" em diferentes condições experimentais e tem sido estimada com espessura aproximada de $40 \mu \mathrm{m}$, um valor bem inferior ao previamente suposto (várias centenas de micrômetros) e não representa a principal barreira para a absorção lipídica. AGL de cadeias curtas e médias, que são solúveis em água atravessam-na facilmente e penetram nos enterócitos. Com o aumento da cadeia carbônica dos AGL, diminui a sua solubilidade na camada de água e aumenta sua partição nas micelas. Embora seja provável que os monômeros livres tenham maior velocidade na camada de água do que as micelas, a concentração das micelas mistas nesta região é efetivamente elevada, o que leva a supor que a difusão micelar seja o mecanismo mais eficiente de trans- 
porte dos produtos da hidrólise lipídica nesta barreira. Cálculos demonstram que realmente a difusão micelar é o mecanismo mais provável, uma vez que, quando comparado com o processo de difusão dos monômeros, a solubilização micelar eleva a concentração dos AGL-CL próximo à ML por um fator de 1.000.000.

$\mathrm{O}$ pH da camada não agitada de água é acídico e este microclima é gerado pelo contratransportador $\mathrm{Na}^{+} / \mathrm{H}^{+}$da ML. Postula-se, assim, que os AGL-CL dissociados das micelas sejam protonados e penetrem a ML dos enterócitos por difusão simples, não iônica. Outra teoria proposta para o influxo dos AGL é a de colisão e incorporação do AGL com a ML, o que seria facilitado pelos movimentos intestinais. Os outros produtos da hidrólise lipídica, os lisofosfolipídeos, os 2-MAG e o colesterol também penetram a ML.

De longa data tem sido proposto que todos estes produtos da hidrólise lipídica seriam transportados através da ML por difusão simples. Atualmente, porém, têm sido identificadas proteínas transportadoras tanto nos enterócitos como nos hepatócitos que transportariam os AGL, o colesterol e os FL através das membranas celulares provavelmente por um processo mediado de difusão facilitada ou por um processo ativo.

Após o influxo dos produtos da hidrólise lipídica nos enterócitos, os sais biliares remanescentes retornam à luz intestinal e são reabsorvidos ao longo do intestino, mas predominantemente no íleo por processo ativo secundário em acoplamento com o $\mathrm{Na}^{+}$. Os sais biliares retornam ao fígado pela circulação enterohepática. Esta recirculação dos sais biliares ocorre várias vezes durante o período digestivo até que o processo de digestão e absorção lipídica termine. Os sais biliares que retornam ao fígado estimulam a secreção de bile pelos hepatócitos, efeito este denominado colerético.

Os produtos da bidrólise lipídica nos enterócitos são objeto de reesterificação e formam os quilomícrons que são exocitados através da MBL e penetram os capilares linfáticos das vilosidades.

No enterócito do jejuno proximal, os produtos da hidrólise lipídica reassociam-se após reesterificação, num processo inverso ao que ocorre na dissociação dos monômeros das micelas. O primeiro passo é a associação dos AGL-CL às proteínas ligadoras de ácidos graxos do citosol (fatt acid binding proteins) ou FABP. Estas proteínas (12 kDa), cujas concentrações são mais elevadas no jejuno proximal, onde ocorre a absorção lipídica, transportam os ácidos graxos de cadeias longas da ML para o retículo endoplasmático liso (REL). Elas também transportam os lisofosfolipídeos, os MAG e o colesterol (Figura 22.17). 


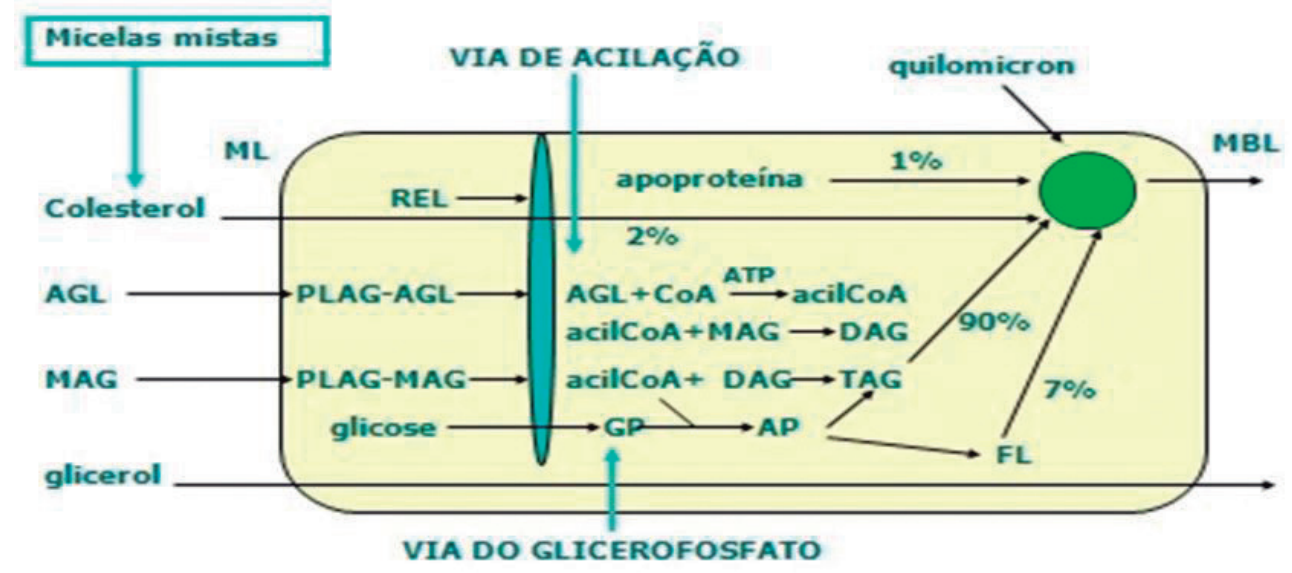

Figura 22.17 - Transporte dos ácidos graxos e dos fosfolipidios através da membrana luminal. $A G \mathrm{~L}=$ ácido graxo livre; AGL-CC = ácido graxo de cadeia curta; $\mathrm{AGL}-\mathrm{CL}=$ ácido graxo de cadeia longa; $2 \mathrm{MG}=2$-monoacilglicerol; $\mathrm{SB}=$ sais biliares. Figura adaptada de Medical Physiology, de Boron WF e Boulpep EL, 2005.

A reesterificação dos produtos da hidrólise lipídica no REL utiliza o 2-MAG como substrato pela denominada via de acilação do monoacilglicerol que predomina durante os processos da digestão e absorção dos lipideos. A outra via, que predomina nos períodos interdigestivos, é do ácido fosfatídico que utiliza o glicerol-3-fosfato do metabolismo glicídico. Ambas vias dependem da ativação de ácidos graxos pela acetil coenzima A (acetil CoA) catalizada pela acil-CoA-sintetase, na presença de ATP e $\mathrm{Mg}^{2+}$. $\mathrm{Na}$ via de acilação os substratos preferenciais são os 2-MAG por serem, inclusive mais abundantes. A acil-CoA-sintetase acila o 2-MAG originando DAG que, por sua vez, originam os TAG. Estas reações ocorrem na face citosólica do do retículo endoplasmático liso (REL).

Os monoacilgliceróis são, pois, acilados pela acil-CoA resultando diacilgliceróis e originando os triacilgliceróis, após nova acilação, em reações catalisadas por acil-transferases específicas. As enzimas responsáveis por estas reações pertencem ao retículo endoplasmático liso que fica repleto de lipídios durante o período absortivo. Esta via é mobilizada nos períodos de jejum. A reesterificação dos ácidos graxos resulta de acilação pela acil-CoA e pelo $\alpha$-glicerofosfato derivado do metabolismo da glicose, originando o ácido fosfatídico. Este, após desfosforilação, forma diacilgliceróis, que sofrem nova acilação gerando triacilgliceróis. O ácido fosfatídico participa, também, da síntese de fosfolipídios no citosol dos enterócitos. A acilação dos lifosfolipídios absorvidos por acil-transferases específicas que também geram fosfolipídios.

O colesterol pode ser reesterificado nos enterócitos, resultando, os ésteres de colesterol, embora seja encontrado, também, sob forma livre. A quantidade de co- 
lesterol livre e reesterificado absorvido depende da quantidade de colesterol da dieta. Quando a sua ingestão diminui, eleva-se a quantidade de colesterol livre na linfa. Os quilomícrons têm diâmetros de 750 a 5.000 A $^{\circ}$ e contêm 80 a $90 \%$ de triacilgliceróis, 8 a 9\% de fosfolipídios, $2 \%$ de colesterol, 2\% de apoproteína e quantidades mínimas de carboidrato. Os fosfolipídios cobrem entre 80 a $90 \%$ da superfície externa dos quilomícrons formando uma monocamada. $\mathrm{O}$ interior dos quilomícrons contém triacilgliceróis e colesterol, mas nenhum fosfolipídio.

Há vários tipos de apoproteínas na linfa intestinal: A, B C e E. A apoproteína $\mathrm{B}$ é imunologicamente similar às VLDL (very low density lipoprotein) e LDL (low density lipoprotein) que podem representar quilomícrons de diferentes densidades. As apoproteínas são essenciais para a formação dos quilomícrons e para absorção lipídica e, na sua ausência, os lipídios acumulam-se nos enterócitos. As apoproteínas são sintetizadas no retículo endoplasmático rugoso (RER) e se movem para a sua luz do REL onde se associam aos TAG ressintetizados. Além de incorporarem as apoproteínas, o empacotamento dos quilomícrons nascentes envolve a adição de colesterol esterificado e dos fosfolipídeos que formam uma bicamada envolvendo-os. Admite-se que vesículas do REL carregam os quilomícrons nascentes para a face cis do sistema de Golgi, onde elas se fundem e liberam seu conteúdo internamente. Enzimas do sistema de Golgi glicosilam as apoproteínas e as vesículas carregando os quilomícrons brotam da face trans do sistema de Golgi e se dirigem à MBL dos enterócitos. A liberação dos quilomícrons pela MBL ocorre por exocitose.

Os TAG com cadeias médias e curtas de ácidos graxos não dependem das micelas mistas dos sais biliares para serem absorvidos. Eles são transferidos através dos enterócitos diretamente para o sangue porta. Por este motivo, estes TAG são utilizados na dieta de pacientes com problemas de má absorção de lipídeos.

\section{Vários tipos de apolipoproteinas sintetizadas pelos enterócitos.}

Estas são as da classe A (apo A-I, apo A-II, apo A-IV e apo A-V), da classe B (apo B-48) e classe C (apo CII). Outras proteínas carregadoras de lipídeos no plasma são as lipoproteínas de baixa densidade (LDL = low density lipoprotein), as de muito baixa densidade (VLDL = very low density lipoprotein) e as de alta densidade (HLDL = high low density lipoprotein). Os enterócitos sintetizam a $11 \%$ e $40 \%$ de VLDLs durante os períodos de jejum por mecanismo independentes da síntese dos quilomícrons. A LDL é sintetizada nos hepatócitos a partir da VLDL. A HDL pode ser derivada do catabolismo dos quilomícrons ou da VLDL, assim como pode ser sintetizada nos hepatócitos e nos enterócitos. No Quadro 22.5, são comparadas as composições e características dos quilomícrons e da VLDL. 
Tanto os quilomícrons como as VLDLs têm suas composições alteradas nos capilares linfáticos e sanguíneos. Antes de serem conduzidos ao fígado, os quilomícrons e as VLDLs alcançam os pulmões e a circulação periférica via capilares. O endotélio dos capilares sanguíneos contém lipases que hidrolisam os triacilgliceróis, originando AGL e MAG que são capturados pelos adipócitos e células musculares. Os quilomícrons remanescentes, contendo agora predominantemente colesterol, são conduzidos ao fígado.

\section{FISIOPATOLOGIA}

Esteatorreia é definida como a excreção de mais de $7 \mathrm{~g}$ de gordura por aproximadamente $150 \mathrm{~g}$ de fezes/dia. Como já mencionamos, muito pouca gordura é excretada nas fezes e a gordura normalmente excretada é proveniente cólon, proveniente da fermentação bacteriana, de células descamadas, sendo cerca de 3 a $4 \mathrm{~g} /$ dia.

Alterações da secreção biliar. Embora os processos de emulsificação das gorduras, de digestão e de absorção possam ser afetados por diminuição da secreção de sais biliares, ainda pode ocorrer emulsificação das gorduras no estômago e no delgado por agentes emulsificadores como ácidos graxos e fosfolipídios. O colesterol e seus ésteres e as vitaminas lipossolúveis são muito menos solubilizáveis do que os ácidos graxos, há comprometimento da absorção destas substâncias na ausência de sais biliares. $\mathrm{Na}$ ausência total a absorção dos ácidos graxos de cadeias longas sofre uma redução de cerca de $50 \%$.

Alterações da área absortiva do delgado. Ocorre em várias enteropatias, como na do glúten, no spru tropical e doenças inflamatórias. Nestas patologias ocorre má absorção intestinal de vários nutrientes. Os lipídeos da dieta são os triacilgliceróis, os fosfolipídeos, o colesterol e seus ésteres. $1 \mathrm{~g}$ de gordura fornece $9 \mathrm{kcal}$. São ingeridas gorduras em excesso no mundo ocidental desenvolvido. $O$ recomendado é que as gorduras devam fornecer apenas $30 \%$ ou menos das calorias dia rias e a média de ácidos graxos saturados deve ser inferior a $10 \%$. 


\section{RESUMO}

1. Os lipídeos da dieta são os triacilgliceróis, os fosfolipídeos, o colesterol e seus ésteres; $1 \mathrm{~g}$ de gordura fornece $9 \mathrm{kcal}$. No mundo ocidental desenvolvido, são ingeridas gorduras em excesso. $\mathrm{O}$ recomendado é que as gorduras devam fornecer apenas $30 \%$ ou menos das calorias diárias e a média de ácidos graxos saturados deve ser inferior a $10 \%$.

2. A hidrólise lipídica inicia-se pelas lipases pré-duodenais, a lingual e a gástrica. A emulsificação das gorduras em suspensão no fluido luminal do TGI começa com a mastigação e prossegue por ação da motilidade gástrica e do delgado. Agentes estabilizadores das gotículas emulsificadas, que inibem suas coalescências, são o colesterol e os fosfolipídios principalmente.

3. No delgado, os sais biliares agem como detergentes, elevando a emulsificação e otimizando a digestão lipídica. As enzimas pancreáticas lipolíticas são a lipase, a colesterol esterase e as fosfolipases A2; que são hidrossolúveis e agem na interface das gotículas com a água.

4. A colipase propicia a ação hidrolítica da lipase. Os produtos finais da hidrólise lipídica são: 2-MAG, ácidos graxos com tamanhos diferentes, lisofosfolipídios, colesterol livre e glicerol.

5. Os produtos da hidrólise lipídica sofrem partição nas micelas dos sais biliares, que os transferem através da camada não agitada de água até membrana luminal (ML) dos enterócitos do jejuno proximal. São absorvidos na forma de monômeros livres e são transportados através da ML, provavelmente por mecanismos mediados.

6. Os ácidos graxos de cadeias longas, os 2-MAG, os fosfolipídios e o colesterol ligam-se a proteínas ligadoras de ácidos graxos dos enterócitos, sendo transportados ao REL, onde são reestericados por duas vias: a de acilação dos MAG, que predomina no período absortivo, e as do ácido fosfatídico, que ocorre nos períodos interdigestivos. 


\section{REFÊRENCIAS BIBLIOGRÁFICAS}

BERNE, R. M.; LEVY, M. N.; KOEPPEN, B. M.; STANTON, B. A. Physiology. 5 ed. Ed. St Louis, Mosby Inc., 2004.

BINDER, H. Y.; REUBEN, A. Nutrient digestion and absorption. In: BORON, W. F.; BOULPAEP, E. L. Medical physiology. WB Saunders Co., 2005.

DEVLIN, T. M. (ed.). Textbook of of Biochemistry with Clinical Correlations. 4 ed. EUA: John Wiley and Sons, Inc., 1997.

HARDIKAR, W.; SUCHY, S. J. Hepatobiliar function. In: BORON, W. F.; BOULPAEP, E. L. Medical Physiology. WB Saunders CO, 2005.

SANIOTO, S. M. L. Fisiologia do Sistema Digestivo. In: DE AIRES, M. M. Fisiologia Básica. Rio de Janeiro: Guanabara Koogan, 1985.

. Fisiologia do Aparelho Digestivo. In: DE AIRES, M. M. Fisiologia Básica.

2 ed. Rio de Janeiro: Guanabara Koogan, 1999.

. Fisiologia do Sistema Digestivo. In: DE AIRES, M. M. Fisiologia Básica. 3 ed. Rio de Janeiro: Guanabara Koogan, 2008.

. Fisiologia do Sistema Gastrintestinal. In: DE AIRES, M. M. Fisiologia Básica. 4 ed. Rio de Janeiro: Guanabara Koogan, 2012.

. Observando a Motilidade do Intestino. In: CURI, R.; PROCÓPIO, J.; FERNANDES, L. C. Praticando Fisiologia. São Paulo: Manole, 2005.

SANIOTO, S. M. L.; AMORIM, J. B. O. Motricidade do aparelho estomatognático: Mastigação e Deglutição. In: CRIVELLO, O. (coord.) Fundamentos de Odontologia. São Paulo: GEN, 2013.

SANIOTO, S. M. L.; AMORIM, J. B.; MANCINI, M. N. G.; BALDO, M. V. Fisiologia da Secreção Salivar. São Paulo: GEN, 2013.

VOET, D.; VOET J. G. Biochemistry. 2 ed. EUA: John Wiley and Sons, Inc., 1995. 
